University of Pennsylvania Carey Law School

Penn Law: Legal Scholarship Repository

Faculty Scholarship at Penn Law

1989

\title{
The Transformation of American Civil Procedure: The Example of Rule 11
}

Stephen B. Burbank

University of Pennsylvania Carey Law School

Follow this and additional works at: https://scholarship.law.upenn.edu/faculty_scholarship

Part of the Civil Procedure Commons, Courts Commons, Judges Commons, Legal Commons, and the Legal History Commons

\section{Repository Citation}

Burbank, Stephen B., "The Transformation of American Civil Procedure: The Example of Rule 11" (1989). Faculty Scholarship at Penn Law. 1399.

https://scholarship.law.upenn.edu/faculty_scholarship/1399

This Article is brought to you for free and open access by Penn Law: Legal Scholarship Repository. It has been accepted for inclusion in Faculty Scholarship at Penn Law by an authorized administrator of Penn Law: Legal Scholarship Repository. For more information, please contact PennlawIR@law.upenn.edu. 


\title{
II. THE UNDERLYING ASSUMPTIONS OF THE FEDERAL RULES OF GIVIL PROGEDURE
}

\author{
THE TRANSFORMATION OF AMERICAN CIVIL \\ PROCEDURE: \\ THE EXAMPLE OF RULE 11*
}

\author{
Stephen B. Burbank $†$
}

\section{INTRODUCTION}

In selecting a pretentious title for this paper, I had three objectives: (1) to satisfy the convener's need in sending out literature about the Conference, (2) to settle upon words sufficiently capacious to accommodate anything I write, and (3) to whet both the appetites of readers of that literature and my own appetite. For you see, I felt like a character in La Grande Bouffe, a movie in which people literally eat themselves to death. Having at that point suffered a steady diet of Rule 11 for more than a year as reporter of the Third Circuit Task Force on Rule 11, I did not want to regurgitate what I had already written; I was not sure that I would have the stomach for more, but I was quite sure that another meal would kill me.

Refreshed by the prospect of publication of the Task Force's Report, ${ }^{1}$ and having no desire either to extend the metaphor or fall victim to the tyranny of a title, I have a modest agenda today. My goal is to assess amended Rule 11 against the claims and stated aspirations of those who gave us the Rules Enabling Act in $1934,{ }^{2}$ the Federal Rules

* $\odot$ Copyright 1989 Stephen B. Burbank

† Professor of Law, University of Pennsylvania. A.B., 1968; J.D., 1973, Harvard University. This Article is a revised version of the paper delivered by the author at the Conference.

2 The report has since been published by the American Judicature Society. See Rule 11 in Transition: The Report of the Third Gircuit Task Force on Federal Rule of Givil Procedure 11 (1989) [hereinafter Task Force Report]. As reporter of the Task Force and principal author of the report, I acknowledge heavy reliance on the analysis and findings in that document. At the same time, I also acknowledge a heavy debt to the members of the Task Force and numerous other individuals who contributed to the final product. See $i d$. at xi-xii.

2 Act of June 19, 1934, ch. 651, \$§ 1 \& 2, 48 Stat. 1064 (1934) (codified as 


\section{of Civil Procedure in 1938, and the amended Rule itself in $1983 .^{3}$ In}

amended at 28 U.S.C. $\S 2072(1982)$ ). As recently amended by Pub. L. No. 100-702, $\S$ 401(a), 102 Stat. 4642, 4648-49 (1988), section 2072 provides:

(a) The Supreme Court shall have the power to prescribe general rules of practice and procedure and rules of evidence for cases in the United States district courts (including proceedings before magistrates thereof) and courts of appeals.

(b) Such rules shall not abridge, enlarge or modify any substantive right. All laws in conflict with such rules shall be of no further force or effect after such rules have taken effect.

The same statute adds a new section 2074, as follows:

(a) The Supreme Court shall transmit to the Congress not later than May 1 of the year in which a rule prescribed under section 2072 is to become effective a copy of the proposed rule. Such rule shall take effect no earlier than December 1 of the year in which such rule is so transmitted unless otherwise provided by law. The Supreme Court may fix the extent such rule shall apply to proceedings then pending, except that the Supreme Court shall not require the application of such rule to further proceedings then pending to the extent that, in the opinion of the court in which such proceedings are pending, the application of such rule in such proceedings would not be feasible or would work injustice, in which event the former rule applies.

(b) Any such rule creating, abolishing, or modifying an evidentiary privilege shall have no force or effect unless approved by Act of Congress.

Id. Both provisions were effective December 1, 1988. See id. at $\S 407$.

${ }^{3}$ As amended in 1983 and 1987, Rule 11 provides:

\section{Signing of Pleadings, Motions, And Other}

PAPERS; SANCTIONS

Every pleading, motion, and other paper of a party represented by an attorney shall be signed by at least one attorney of record in the attorney's individual name, whose address shall be stated. A party who is not represented by an attorney shall sign the party's pleading, motion, or other paper and state the party's address. Except when otherwise specifically provided by rule or statute, pleadings need not be verified or accompanied by affidavit. The rule in equity that the averments of an answer under oath must be overcome by the testimony of two witnesses or of one witness sustained by corroborating circumstances is abolished. The signature of an attorney or party constitutes a certificate by the signer that the signer has read the pleading, motion, or other paper, that to the best of the signer's knowledge, information, and belief formed after reasonable inquiry it is well grounded in fact and is warranted by existing law or a good faith argument for the extension, modification, or reversal of existing law, and that it is not interposed for any improper purpose, such as to harass or to cause unnecessary delay or needless increase in the cost of litigation. If a pleading, motion, or other paper is not signed, it shall be stricken unless it is signed promptly after the omission is called to the attention of the pleader or movant. If a pleading, motion, or other paper is signed in violation of this rule, the court, upon motion or upon its own initiative, shall impose upon the person who signed it, a represented party, or both, an appropriate sanction, which may include an order to pay to the other party or parties the amount of the reasonable expenses incurred because of the filing of the pleading, motion, or other paper, including a reasonable attorney's fee.

FED. R. Giv. P. 11 (the 1987 amendments made the Federal Rules gender neutral. 
doing so, I shall bring to bear on the issues an analytical framework and empirical data that the Task Force developed in the preparation of its Report. My hope is that normative and empirical perspectives on this still-recent innovation will inform judgments about the future of Rule 11. ${ }^{4}$ Perhaps the exercise also will inform debates about the future of American civil procedure and hence at least excuse, if not justify, my title.

In measuring Rule 11 against these claims and stated aspirations, it is important to note at the outset characteristics of the Rule and its history that may affect conclusions to be drawn for its future and about any more general conclusions.

First, Rule 11 was amended but six years ago, and the amended Rule was avowedly an experiment. The Advisory Committee knew little about experience under the original Rule, ${ }^{5}$ knew little about the perceived problems that stimulated the efforts leading to the two packages of Rules amendments in 1980 and $1983,{ }^{6} \mathrm{knew}$ little about the jurisprudence of sanctions, ${ }^{7}$ and knew little about the benefits and costs of sanctions as a case management device. ${ }^{8}$ Some of these gaps re-

They were not intended to have any other effect.)

- For a discussion of this approach to legal scholarship, see Rubin, The Practice and Discourse of Legal Scholarship, 86 Mich. L. REv. 1835, 1891-1904 (1988). See also Burbank, Plus Cha Change . . . ?, 21 U. Mrch. J.L. Ref. 509, 512-13 (1988). $\checkmark$ "Experience shows that in practice Rule 11 has not been effective in deterring abuses. See 6 [sic] Wright \& Miller, Practice and Procedure: Civil § 1334 (1971)." FED. R. GIv. P. 11 advisory committee note. The cited work asserts that "there is little evidence of frequent use of sanctions for the violation of Rule 11." $5 \mathrm{C}$. WRIGHT \& A. Miller, Federal Practice and Procedure $§ 1334$, at 503 (1969); see also Risinger, Honesty in Pleading and its Enforcement: Some "Striking" Problems with Federal Rule of Civil Procedure 11, 61 MinN. L. REv. 1, 34-37 (1976) (between 1938 and 1976, only eleven reported cases resulted in a finding that Rule 11 was violated). Presumably the authors were relying on published opinions. The Task Force's empirical work suggests that published opinions are an unreliable basis for judgment. See infra text accompanying note 164; $c f$. A. MILLER, THE AugusT 1983 AMENDMENTS to the Federal Rules of Givil Procedure: Promoting Effective Case MaNAGEMENT AND LAWYER RESPONSIBILITY 38 (1984) (discovery sanctions often are not reported).

For reference to the emphasis on sanctions in the 1983 amendments as an "experiment," see $i d$. at 40 .

' See Rosenberg, Federal Rules of Civil Procedure in Action: Assessing Their Impact, 137 U. PA. L. REv. 2197, 2198-2202 (1989).

7 See Burbank, Sanctions in the Proposed Amendments to the Federal Rules of Civil Procedure: Some Questions About Power, 11 HoFSTRA L. REv. 997, 999-1002 (1983).

${ }^{8}$ Theme two is then addressed directly to the bench. Every empirical study that we have (and I shouldn't magnify that, because there aren't many empirical studies and each one has a flaw here or a mole there or a wart elsewhere) is loud and clear on one proposition: increased judicial management .... in the pretrial process cuts down the time frame from institution to pretrial determination, or resolution. . . . 
present continuity rather than change in that most important part of American civil procedure that we call federal court rulemaking. In particular, whatever ties some of the original rulemakers had to the realist movement, ${ }^{9}$ most (but not all) of their successors have severed the empirical cord. ${ }^{10}$ Yet, however little time it takes to conceive an experiment, it may take far more time to conduct it and to evaluate the results. ${ }^{11}$ In the case of amended Rule 11, there is a serious risk of prematurity in judgment. Interpretations of, and attitudes towards, the amended Rule are evolving. Although assessments of experience under the amended Rule need no longer proceed in an empirical vacuum, the available data are of limited utility to that end beyond the confines of the Third Circuit. ${ }^{12}$

Second, as is well known but easily forgotten, the 1983 amendment of Rule 11 was but one of a number of amendments, a package, moreover, that was sent to Congress only three years after another. ${ }^{13}$ Taken together, the amendments of the Eighties may be thought to chart new directions in federal civil procedure, rendering an assessment in terms of claims and stated aspirations in 1938 or 1934, let alone $1926,{ }^{14}$ an exercise in nostalgia, if not irrelevancy. In any event, that possibility enhances the importance of being precise about the measur-

.. Theme four I like to think of as the mortar holding the first three bricks together. Simply put, it is sanctions. How do you achieve themes one [increased lawyer responsibility], two [increased judicial management], and three [reduced discovery abuse]? One answer chosen by the rulemakers is to impose sanctions.

A. Miller, supra note 5, at 10-11.

For one example of the common view that a judge who is an effective case manager rarely if ever needs to resort to sanctions, see TASK FORCE REPORT, supra note 1, at 65. See also Burbank, The Costs of Complexity (Book Review), 85 Mich. L. REv. 1463,1478 \& n.83 (1987).

See Schlegel, American Legal Realism and Empirical Social Science: From the Yale Experience, 28 Buffalo L. Rev. 459, $495-98$ (1979); Shapiro, Federal Rule 16: A Look at the Theory and Practice of Rulemaking, 137 U. PA. L. REv. 1969, 1973 (1989).

10 See Rosenberg, supra note 6, at 2200-02, 2211; see also Weinstein, After Fifty Years of the Federal Rules of Civil Procedure: Are the Barriers to Justice Being Raised?, 137 U. PA. L. REv. 1901, 1903 (1989) (little empirical data available).

${ }^{11}$ Cf. Burbank, Of Rules and Discretion: The Supreme Court, Federal Rules and Common Law, 63 Notre Dame L. Rev. 693, 717 (1988) ("We are constantly reminded that 'judicial reform is no sport for the short-winded,' but often the quip more accurately describes the time it takes to sell a proposed reform than the time invested in conceiving it." (footnotes omitted)).

12 See TASK FORCE REPORT, supra note 1, at 56, 75.

is See Burbank, supra note 7 , at $997-1000$. The 1983 amendments included revisions of Rules 6,7,11,16,26,52,53, and 67, and added new Rules 72-76.

14 See Burbank, The Rules Enabling Act of 1934, 130 U. PA. L. REv. 1015, 1083-89 (1982); Burbank, supra note 11, at 713 n.137. 
ing rod one is using. ${ }^{15}$

Third, if it is true that "the trend of modern procedural law has been away from rules that make policy choices towards those that confer on trial courts a substantial amount of normative discretion,"16 Rule 11 must be considered a "notable exception[]"17 in its command to impose sanctions upon finding a violation.

\section{UNIFORMITY}

Proponents of the Enabling $\mathrm{Act}^{\mathbf{1 8}}$ and of the original Federal Rules ${ }^{19}$ sold both on the promise that uniform federal procedure would be superior to federal procedure under the Conformity Act of $1872,{ }^{20}$ which yielded a melange of state and federal law. The arguments advanced by the sellers as well as the counter-arguments advanced by opponents need not detain us. Professor Subrin's paper supports the view that, whoever had the better of the debate then, it would be hard to call federal procedure uniform today. ${ }^{21}$ The Federal Rules may appear uniform, but many of them merely empower district judges to make ad hoc decisions. They may "largely eschew borrowing [of state law], but they are nonetheless heavily in debt."222 They are, in sum, the tip of an iceberg. Below the water line lies "a bewildering array of local rules, standing orders, and standard operating procedures, to say nothing of case law."23

15 Judge Weinstein has turned this speculation into an argument, quoting me out of context. See Weinstein, supra note 10, at 1913 . He also attempts to hold a mirror to my previous observation that he engaged in "wishful thinking," Burbank, The Chancellor's Boot, 54 BROokLYN L. Rev. 31, 33 (1988), which is puzzling because he acknowledges our agreement "that access should not be denied." Weinstein, supra note 10 , at 1913.

18 Burbank, supra note 11 , at 715 .

17 Id.; see also Burbank, supra note 7, at 1008-10.

18 First, to make uniform throughout the United States the forms of process, writs, pleadings, and motions and the practice and procedure in the district courts in actions at law. It is believed that if this were its only advantage that [sic] lawyers and litigants would find, in uniformity alone, a tremendous advance over the present system.

S. Rep. No. 1174, 69th Cong., 1st Sess. 1-2 (1926) [hereinafter 1926 Senate REPORT].

19 See, e.g., Rules of Civil Procedure for the District Courts of the United States: Hearings Before the House Comm. on the Judiciary, 75th Cong., 3d Sess. 2 (1938) [hereinafter Hearings] (testimony of Attorney General Cummings).

${ }^{20}$ Act of June 1, 1872, ch. 255, §§ 5 \& 6, 17 Stat. 196, 197.

21 See Subrin, Federal Rules, Local Rules, and State Rules: Uniformity, Divergence, and Emerging Procedural Patterns, 137 U. PA. L. REv. 1999, 2018-21 (1989); Coquillette, Squiers \& Subrin, The Role of Local Rules, 75 A.B.A. J. 62 (1989).

22 Burbank, supra note 11, at 715.

${ }^{23}$ Id. But see Weinstein, supra note 10 , at 1902, 1911-12. It is hard to take seriously claims of uniformity (or attempts to downplay a lack of uniformity) by a 
But surely Rule 11 is different. After all, rather than conferring normative discretion on district judges, the Rule purports at one critical point to take it away. Moreover, although local rules and standing orders elaborating its requirements are not unknown, they have not been a growth industry. ${ }^{24}$

Alas, Rule 11 is not different. Even after a six-year period that has witnessed some sharp turns by courts ${ }^{26}$ and commentators ${ }^{26}$ alike (which have brought more of them together), there is a conflict between or among circuits on practically every important question of interpretation and policy under the Rule, from the content of the duties imposed on a person who signs a paper filed in district court, ${ }^{27}$ to the procedural rights of those who may be sanctioned, ${ }^{28}$ the persons or entities on whom sanctions may be imposed, ${ }^{29}$ the standard(s) of appellate review, ${ }^{30}$ and even to whether sanctions are in fact mandatory for a viola-

federal judge who proclaims that in his courtroom "the federal rules are of little significance in day-to-day practice." Weinstein, The Ghost of Process Past: The Fiftieth Anniversary of the Federal Rules of Civil Procedure and Erie, 54 BROOKLYN L. REv. 1, 28 (1988). Moreover, Judge Weinstein's discussion, for example, of experience under Rule 11, Rule 23, and Rule 56, and of special pleading requirements, see Weinstein, supra note 10, at 1913-16 hardly suggests uniformity. Is this the "experimentation" Judge Weinstein favors, see id. at 1911, or the "procedural subterfuge" he decries? Id. at 1919. What other than "personal politics and wishful thinking," see supra note 15, determines the label? "If judges are given broad discretion, and district courts may vary widely in the local rules and standing orders they adopt, one should not expect any significant degree of uniformity from judge to judge, court to court, or case to case." Shapiro, supra note 9, at 1993-94.

${ }_{24}$ See Letter from Mary P. Squiers, Esq., to Stephen B. Burbank (Jan. 11, 1989) (reporting findings of Judicial Conference's Local Rules Project) (copy available from author).

${ }_{25}^{25}$ Compare Robinson v. National Cash Register Co., 808 F.2d 1119, 1125-32 (5th Cir. 1987) (Rule 11 imposes a continuing obligation and appellate review is under tripartite standard) with Thomas v. Capital Sec. Serv., Inc., 836 F.2d 866 (5th Cir. 1988) (en banc) (no continuing obligation under Rule 11 and unitary standard of review applies).

${ }_{26}$ Compare Schwarzer, Sanctions Under the New Federal Rule 11 - a Closer Look, 104 F.R.D. 181 (1985) (bullish) with Schwarzer, Rule 11 Revisited, 101 Harv. L. Rev. 1013 (1988) (bearish).

${ }_{27}$ Compare Herron v. Jupiter Transp. Co., 858 F.2d 332, 335-36 (6th Cir. 1988) (Rule 11 imposes a continuing obligation) with Thomas, 836 F.2d at 874-75 (no continuing obligation under Rule 11).

${ }^{28}$ Compare United States v. Childers, 846 F.2d 74 (4th Gir. 1988) (text in WESTLAW and LEXIS) (Rule 11 sanction imposed without prior opportunity to be heard affirmed) with Sanko S.S. Co. v. Galin, 835 F.2d 51 (2d Cir. 1987) (similarly imposed sanction reversed).

${ }^{29}$ Compare Calloway v. Marvel Entertainment Group, 854 F.2d 1452, 1478-81 (2d Cir. 1988) (Rule 11 sanction may be imposed on a law firm), cert. granted sub. nom. Pavelic \& Leflore v. Marvel Entertainment Group, 109 S. Ct. 1116 (1989) with Robinson, 808 F.2d at 1128-29 (non-signing partner may not be sanctioned under Rule 11).

${ }_{30}$ See Kale v. Combined Ins. Co., 861 F.2d 746, 756-58 (1st Cir. 1988); TasK FORCE REPORT, supra note 1 , at $45-46$. 
tion..$^{31}$ Moreover, intracircuit conflicts are not uncommon, ${ }^{32}$ and in a number of circuits there is no appellate law at all on numerous important questions of interpretation.

There is, of course, an easy (to state, not to implement) answer to intracircuit disuniformity; indeed, in the last year or so, a number of en banc opinions have sought to put Rule 11 questions to bed, even those not ready for it. ${ }^{33}$ Similarly, in some circuits where appellate law on Rule 11 is not well developed, panels have sought to fill the void, perhaps on the theory that dictum, especially if it is repeated, is better than silence. ${ }^{34}$

As for intercircuit conflicts, the Supreme Court is available, and its failure to take a Rule 11 case to date may suggest that it is waiting for the issues to "percolate"35_an unfortunately apt metaphor for issues that bring so many lawyers' blood to the boiling point.

Is it, then, unfair to tax the amended Rule with failing the test of uniformity? Perhaps. Perhaps also that is no longer a useful test in light of the movement toward individual case management, a movement best reflected in other amendments that became effective in 1983, notably to Rule $16 .^{36}$ Looking at the question from both perspectives may help to formulate goals for the Federal Rules of the future.

It is possible that, after an additional period that includes a few authoritative pronouncements by the Supreme Court, Rule 11 will be not only formally uniform in its application in all federal trial courts, but will yield, within acceptable limits that account for differences among cases, uniform results. Uniformity of result was, as Professor

${ }^{31}$ Compare Oliveri v. Thompson, 803 F.2d 1265, 1280 (2d Cir. 1986) (no sanctions necessary for de minimis violations), cert. denied sub nom. County of Suffolk v. Graseck, 480 U.S. 918 (1987) with.Thomas, 836 F.2d at 876 (stating that there are "no longer any 'free passes' for attorneys and litigants who violate Rule 11").

${ }^{32}$ See, e.g., FDIC v. Tekfen Constr. \& Installation Co., 847 F.2d 440, 443 (7th Cir. 1988) (standard of appellate review). I speak here of conflicts in the rule or standard only, not in the ways in which a supposedly uniform rule or standard is applied. See infra text accompanying notes $38-48$.

${ }_{33}$ See, e.g., Thomas, 836 F.2d 866; Donaldson v. Clark, 819 F.2d 1551 (11th Gir. 1987) (en banc).

st See, e.g., Gaiardo v. Ethyl Corp., 835 F.2d 479, 482-85 (3d Cir. 1987).

ss See, e.g., United States v. Mendoza, 464 U.S. 154, 160 (1984) (noting that "[a]llowing only one final adjudication would deprive this Court of the benefit it receives from permitting several courts of appeals to explore a difficult question"); S. Estreicher \& J. Sexton, Redefining the Supreme Court's Role: A Theory of Managing the Federal Judicial Process 48-52, 73-74 (1986). After this paper was delivered, the Supreme Court granted certiorari in Pavelic \& Leflore v. Marvel Entertainment Group, 109 S. Ct. 1116 (1989). The grant, however, is restricted to a narrow issue, suggesting that guidance on other more fundamental questions will come by way of dictum or await future cases.

${ }^{36}$ See A. Mrller, supra note 5, at 10, 19-30; Subrin, supra note 21, at 2022-23. 
Subrin explains in his paper, an ultimate goal of proponents of the Enabling Act. ${ }^{37}$ Moreover, it must be a goal, however difficult to attain, of a system that aspires to equal justice-procedural and substantive. In the case of Rule 11, it is a goal that may be impossible to attain.

Behind some of the conflicts, inter- and intra-circuit, to which I have referred lie differences deeper than disagreement on this or that point of doctrine. Those differences extend to the purposes of amended Rule $11,{ }^{38}$ and they reflect differences about the values that procedural rules serve or should serve. As an example, some judges are using Rule 11 to shift the expenses they deem "unjustified," caused by papers they deem "frivolous," to the lawyer or litigant they deem responsible for the filing of the paper. ${ }^{39}$ The results may include (1) an incursion into the American Rule on attorney's fees as deep as the notion of frivolity is subjective, ${ }^{40}(2)$ a view of sanctioning procedure that at times seems to impute greater rights to one who makes a Rule 11 motion than to one against whom such a motion is made, ${ }^{41}$ (3) a narrowing of the normative discretion that the Rule unquestionably confers on trial judges to select an appropriate sanction, ${ }^{42}$ and (4) a narrowing of the allocative discretion that an appellate court truly concerned about the costs of satellite litigation happily would leave with trial judges. ${ }^{43}$ This is by no means a complete list of the possible results of giving primacy to legal products and to a compensatory goal in the interpretation and implementation of amended Rule 11. It may, however, suffice to suggest that equal justice will be possible under Rule 11 only when federal judges subordinate their own normative preferences to the stated nor-

37 See Subrin, supra note 21 , at 2002-06 see also Burbank, supra note 14 , at 1049.

s8 See TASK Force REPORT, supra note 1, at 9-52.

s9 See, e.g., Hays v. Sony Corp., 847 F.2d 412, 417-18 (7th Cir. 1988); S.A. Auto Lube, Inc. v. Jiffy Lube Int'l, Inc., 842 F.2d 946, 948-49 (7th Cir. 1988); Szabo Food Serv., Inc. v. Canteen Corp., 823 F.2d 1073, 1077 (7th Cir. 1987), cert. dismissed, 108 S. Ct. 1101 (1988); Dreis \& Krump Mfg. Co. v. International Ass'n of Machinists, 802 F.2d 247, 254 (7th Gir. 1986); In re TCI, Ltd., 769 F.2d 441, 445 (7th Cir. 1985) (dictum).

to See Hays, 847 F.2d at 419 ("Rule 11 is a fee-shifting statute"). But see TASK ForCe REPORT, supra note 1 , at 10-12, 18-19.

1 See Szabo Food Serv., 823 F.2d at 1082-84; Tarkowski v. County of Lake, 775 F.2d 173, 176 (7th Gir. 1985) (Rule 11 and $\S 1988$ ). But see TASK ForCE REPORT, supra note 1 , at $35-36,74$.

${ }^{42}$ See S.A. Auto Lube, 842 F.2d at 950-51; Eastway Constr. Co. v. New York, 762 F.2d 243, 254 n.7 (2d Cir. 1985). But see TASK FORCE REPORT, supra note 1, at 48. For a discussion of normative and allocative discretion, see Shapiro, Jurisdiction and Discretion, 60 N.Y.U. L. REv. 543, 545-47 (1985).

${ }^{43}$ See Brown v. Federation of State Med. Bds., 830 F.2d 1429, 1434 \& n.3 (7th Cir. 1987); Eastway, 762 F.2d at 254 n.7. But see TASK FORCE REPORT, supra note 1, at $45-47$. 
mative preferences of the Rule and of the rulemakers.

If Rule 11 is to be more than superficially uniform, it will not be sufficient to recognize that deterrence of abuse is its most important goal. ${ }^{44}$ That would leave lower courts, and even judges on the same court, free to pursue a subsidiary goal of compensation, and some of them would do so routinely and relentlessly. ${ }^{45}$ Rather, courts should regard compensation not as end (goal) in itself, but as one among many means available, through the choice of an appropriate sanction, to advance the goal of deterrence. In doing so, they would be faithful to the language of the Rule and to its Advisory Committee Note. ${ }^{46}$

Equally important, só long as the abuses at which Rule 11 is directed are defined to include papers deemed legally frivolous, the detection of violations will be as determinate, and hence as uniform, as the notion of frivolousness itself. ${ }^{47}$ Courts should cease reading Rule 11 in the teeth of its language and thus cease reading it to reach legal products in addition to the conduct responsible for those products. Of course product may in an appropriate case ground an inference about conduct. Talk about inferences is a smoke-screen, however, unless a judge is prepared to consider conduct and would find no violation when presented with persuasive evidence of reasonable pre-filing inquiry and

14 See, e.g., Thomas v. Capital Sec. Serv., Inc., 836 F.2d 866, 876 (5th Cir. 1988) (en banc); Brown, 830 F.2d at 1438.

${ }_{45}$ See S.A. Auto Lube, 842 F.2d at 950; cf. Note, A Uniform Approach to Rule 11 Sanctions, 97 YaLE L.J. 901, 905-07 (1988) (discussing differing judicial perceptions of the purpose of Rule 11).

${ }^{16}$ See FED. R. Crv. P. 11 advisory committee note ("The word 'sanctions' in the caption ... stresses a deterrent orientation .... "). The Third Circuit Task Force recommends:

(2) Deterrence of abuse by the person sanctioned (specific deterrence) should be regarded as Rule 11's most important goal, and courts should pursue other goals only to the extent necessary or appropriate to attainment of specific deterrence. Compensation should be regarded as one (among many) means to the end of deterrence, not as an end in itself.

TASK FORCE REPORT, supra note 1, at 96.

${ }_{47}$ The Third Circuit Task Force recommends:

(3) The abuses for which Rule 11 sanctions are imposed should be both deterrable and remediable. They should comprise the conduct specified in the Rule itself and the Advisory Committee Note, as elaborated in case law. They should not include the "abuse" of a frivolous product, which is not there specified, which may be neither deterrable nor remediable, and the subjectivity of judgment about which, particularly as to matters of law, threatens to overwhelm the Advisory Committee's cautions about "using the wisdom of hindsight" and "chill[ing] an attorney's enthusiasm or creativity in pursuing factual or legal theories." On the other hand, in assessing conduct and representations about conduct, a court should in appropriate cases draw inferences from product.

Id. at 96-97; see also infra text accompanying notes 90-92, 96-97; infra note 124. 
of an honest conclusion based on such inquiry that the paper in question was "well grounded in fact and . . . warranted by existing law or a good faith argument for the extension, modification or reversal of existing law." 48

These steps would go a long way toward achieving greater uniformity in determinations that Rule 11 has or has not been violated. They would not, however, promote uniformity in the sanctions imposed; indeed, quite the reverse. Would not routine expense-shifting be better from that perspective?

For present purposes the problem would be, again, that the Rule would be only superficially uniform. Rule 11 sanctions are intended to affect conduct, both that of the violator (specific deterrence) and that of others (general deterrence). They are intended to chill certain conduct but not other conduct. Sanctions, monetary or non-monetary, can affect people in different ways. In this case, the Advisory Committee had been alerted to the risks of differential impact, and it sought to minimize at least some of them. ${ }^{49}$ Routine resort to expense-shifting under Rule 11, particularly expense-shifting on an attorney's fee model, is inconsistent with the trial court's duty to exercise discretion in selecting a sanction appropriate to the goal of specific deterrence and its duty to avoid over-deterrence, specific or general. ${ }^{50}$

Professor Carrington would have us believe that, in using the phrase "general rules" in the Rules Enabling Act of 1934, ${ }^{\text {,1 }}$ Congress intended not only that the same Federal Rules be applicable in all federal district courts, but that the same Rules be applicable in all types of cases, that, in other words, the Rules be not only uniform but also

48 FED. R. Civ. P. 11; see also TASK ForCe RePort, supra note 1, at 20, 23. "Pre-signing inquiry" would be more precise, but "pre-filing inquiry" has become standard usage.

49 The rule is not intended to chill an attorney's enthusiasm or creativity in pursuing factual or legal theories. The court is expected to avoid using the wisdom of hindsight and should test the signer's conduct by inquiring what was reasonable to believe at the time the pleading, motion, or other paper was submitted. ...

... Although the standard is the same for unrepresented parties . . . the court has sufficient discretion to take account of the special circumstances that often arise in pro se situations. ...

...

... The word "sanctions" in the caption . . . stresses a deterrent orientation in dealing with improper . . . papers. . . . The court, however, retains the necessary flexibility to deal appropriately with violations of the rule. It has discretion to tailor sanctions to the particular facts of the case.

FED. R. Crv. P. 11 advisory committee note.

so See infra text accompanying notes 97-100.

s1 This language has survived the recent amendments. See supra note 2. 
trans-substantive. ${ }^{52}$ I know of no support for that proposition in the legislative history of the $1934 \mathrm{Act}^{\mathrm{53}}$ or in its "antecedent period of travail." Moreover, I encourage those with even the most fleeting interest in politics to consider the rest of Professor Carrington's defense of trans-substantive rules. ${ }^{.5}$ The notion appears to be that judges can be relied upon to bridge the gap between formal equality and inequality in fact, or that in any event the costs of acknowledging the differential impact of Federal Rules that are only trivially uniform and trans-substantive outweigh the benefits.

Professor Carrington is alert to the costs of departing from the appearance of "political neutrality"se but deaf to the costs of what Judge Weinstein calls "procedural subterfuge." Indeed, at times he

52 See Carrington, Continuing Work on the Civil Rules: The Summons, 63 NoTRE DAME L. REv. 733, 741 (1988). Dialogue at the Conference appears to have caused some retreat from this position. See Carrington, Making Rules to Dispose of Manifestly Unfounded Assertions: An Exorcism of the Bogy of Non-Trans-Substantive Rules of Civil Procedure, 137 U. PA. L. REv. 2067, 2079 (1989) [hereinafter Carrington, Bogy]. But, we are now told, "generalism in procedure rules for Article III courts may have constitutional roots in the fifth amendment." Id. at 2081.

${ }^{53}$ For a discussion and analysis of "general rules" as used in the Enabling Act, see letter from Stephen B. Burbank to Committee on Rules of Practice and Procedure (Feb. 27, 1984), reprinted in Hearing on H.R. 2633 and H.R. 3550 Before the Subcomm. on Courts, Civil Liberties, and the Admin. of Justice of the House Comm. on the Judiciary, 99th Cong., 1st Sess. 24-31 (1985).

Although an intent to require trans-substantive procedure is not fairly imputed to Congress, that characteristic probably was assumed by the original rulemakers. See Burbank, supra note 11, at 714 n.140; Subrin, supra note 21, at 2006.

54 Jaffin, Federal Procedural Revision, 21 VA. L. REv. 504, 504 (1935).

Bs See Carrington, Bogy, supra note 52, at 2067-87.

${ }^{58} I d$. at 2074-79.

${ }^{87}$ Weinstein, supra note 10, at 1919. Professor Hazard, on the other hand, clearly recognizes the phenomenon. Indeed, one of his arguments seems to be that criticisms of trans-substantive procedure are naive or misdirected from the perspective of practical politics because "[t]he dynamic of social justice litigation has been the use of existing general forms of procedure for new substantive purposes." Hazard, Discovery Vices and Trans-Substantive Virtues in the Federal Rules of Civil Procedure, 137 U. PA. L. REv. 2237, 2247 (1989). This is hardly an answer to those, like myself, who are not concerned about a specific social agenda (except to the extent that concern about democracy and rights can be characterized as such). See, e.g., Burbank, supra note 8, at 1473-76; Subrin, supra note 21, at 2050-51. Moreover, those who have such an agenda also may find revealing Professor Hazard's invocation of the "Due Process principle" in connection with his assertion that "[t]rans-substantivity of procedure is a principle to which commitment is shared by persons of such different substantive orientations as, for example, Judge Posner and Judge Carter." Hazard, supra, at 2247. Social reformers know all about "commitment." They know, for instance, that something is lost in the translation of some "commitments" into action. Consider in that regard Judge Posner's views on due process in imposing sanctions under Federal Rule of Appellate Procedure 38:

But obviously the right to a hearing, whether that right is implicit or . . . explicit, is limited to cases where a hearing would assist the court in its decision. . . . Where, as in this and most Rule 38 cases, the conduct that 
appears to swallow his own propaganda, as when he portrays as a central feature of our legal system, upon which Congress "relies," class action amendments in $1966,{ }^{59}$ yet fails to acknowledge that the impact of those amendments on power relations was anticipated, if not intended, by his predecessor, Judge Kaplan. ${ }^{60}$

In effect, Professor Carrington identifies as "political" only that which is recognized as of interest by some coherent (and, apparently, wholly self-interested) group. ${ }^{61}$ According to this view, "neutrality" means "reduc[ing] the level of political interest in procedural rules." 62 And according to this view, both substance-specific procedures and empirical investigation of supposedly neutral rules are anathema: the former because they will be likely to attract rather than "deflect political attention"63 and the latter because data on experience under the Rules may cause organized groups to realize that they have a stake and hence to regard the "neutral" rule as a legitimate object of political interest.

From this perspective, amended Rule 11 and some of the other 1983 amendments $^{64}$ do mark a new direction, signalling a more candid recognition that different cases may have different requirements. The question, of course, is whether and when the only or the best answer to

is sought to be sanctioned consists of making objectively groundless legal arguments in briefs filed in this court, there are no issues that a hearing could illuminate. All the relevant "conduct" is laid out in the briefs themselves; neither the mental state of the attorney nor any other factual issue is pertinent to the imposition of sanctions for such conduct. Where a hearing would be pointless it is not required.

Hill v. Norfolk \& W. Ry., 814 F.2d 1192, 1201-02 (7th Cir. 1987).

Professor Hazard's other argument is that, viewing the entire landscape of procedure, the Federal Rules are really not that important. See Hazard, supra, at 2244-46. This is a variation on a familiar rhetorical theme, interesting only because of its persistence and because, in playing the variations, Professor Hazard does not practice what he preaches: political realism. See Burbank, Afterwords: A Response to Professor Hazard añd a Comment on Marrese, 70 CORNELl L. REV. 659, 661-62 (1985); see also infra note 81.

${ }^{88}$ See Carrington, Bogy, supra note 52, at 2071.

${ }^{39}$ See id.; Fed. R. Giv. P. 23. (1989).

${ }^{60}$ See Kaplan, Comment on Carrington, 137 U. PA. L. Rev. 2125, 2126-27

${ }^{61}$ Not even the Supreme Court shares this impoverished view. Recently, the Court adduced Rule 23 in support of the proposition that "this Court's rulemaking under the enabling acts has been substantive and political in the sense that the rules of procedure have important effects on the substantive rights of litigants." Mistretta v. United States, 109 S. Ct. 647, 665 (1989) (footnote omitted); see also id. at 665 n.19.

${ }^{62}$ Carrington, Bogy, supra note 52, at 2085; see also Leubsdorf, Constitutional Civil Procedure, 63 TEx. L. REv. 579, 614 (1984) ("Those who suffer from a bad procedural rule usually do not know in advance that they will be its victims, or even that the rule exists, and are usually scattered and disorganized.").

${ }^{63}$ Carrington, Bogy, supra note 52 at 2079.

${ }^{64}$ See, e.g., FED. R. Civ. P. 16, 26(b)(1). 
that perception lies in reliance on the discretion of judges, guided by general directions that usually are not informed by empirical study, to deliver on the promise of equal justice. Even the experience under Rule 11 in a circuit whose judges, by and large, have not amended the Rule in pursuit of their normative preferences furnishes reasons to be concerned about discretionary justice.

We know that for a one-year period in the Third Circuit, Rule 11 had a disproportionately adverse impact on plaintiffs, in that plaintiffs or their counsel were the targets of two-thirds of the motions made during that period and were sanctioned at a higher rate $(15.9 \%)$ than defendants (9.1\%). Plaintiffs or their counsel also were the object of six of the eight sanctions imposed by courts on their own motion. Considering sanctions imposed on motion and sua sponte, plaintiffs accounted for $77.8 \%$ (21 of 27 ) of the sanctions in the Task Force's survey. ${ }^{65}$ What should we do with such information?

One possibility is to consider an amendment to Rule 12(a), which, by providing only twenty days to answer a complaint, ${ }^{66}$ constitutes "an institutional invitation to defendants not to take seriously the duty of reasonable pre-filing inquiry." ${ }^{277}$ Empirical study might find that extensions are routine, but an amendment expanding the basic period (and limiting extensions) nonetheless might help to alter what appears to be a widespread misimpression that Rule 11 is intended (if not exclusively, then primarily) for plaintiffs. ${ }^{68}$ Another possibility, through an amendment or case law, is to discourage routine resort to expense-shifting as a sanction, on the hypothesis, supported by empirical evidence, that "[t]he paper of choice in the fee-shifting game is the complaint" and that "[p]laintiffs . . . lack a comparable pot of gold . . . because in most cases . . . the answer is not a likely candidate for Rule 11 sanctions." finance on incentives under Rule 11, starting with the hypothesis, again supported by empirical evidence, that the contingent fee is confined largely to the representation of plaintiffs and speculating, I hope not unreasonably, that lawyers are more likely to spend their clients'

6s See TASK FORCE REPORT, supra note 1, at 65. The findings that plaintiffs were the targets of $67 \%$ of Rule 11 motions and that they accounted for $77.8 \%$ of the total sanctions are statistically significant at a level of less than one percent. The finding that plaintiffs are sanctioned at a higher rate on motion is not statistically significant.

Be "A defendant shall serve an answer within 20 days after the service of the summons and complaint upon that defendant. . . FED. R. Civ. P. 12(a).

${ }_{67}$ TASK FORCE REPORT, supra note 1, at 68; see also Joseph v. United States, 121 F.R.D. 406, 410 (D. Haw. 1988).

6s See TASK FORCE REPORT, supra note 1, at 66-67.

$69 \mathrm{Id}$. at 67. 
money on Rule 11 motions than they are to spend their own. ${ }^{70}$

We also know that for the same one-year period in the Third Circuit, Rule 11 had a disproportionately adverse impact on civil rights plaintiffs, in that civil rights plaintiffs, their lawyers, or both were sanctioned at a rate $(47.1 \%)$ far higher than the rate for plaintiffs as a whole $(15.9 \%)$, and higher still than the rate for plaintiffs in non-civil rights cases $(8.45 \%){ }^{71}$ Again, what should we do with such information? Should we consider that, quite apart from Rule 11, some federal courts have imposed pleading requirements on civil rights plaintiffs ${ }^{\mathbf{2}}$ that are more stringent than Rule $8^{73}$ would seem to authorize? Should we be more precise about what we mean by a "civil rights case" and, if we find that $\S 1983$ actions constitute a disproportionately large slice of the Rule 11 pie, consider whether they have characteristics that render this or that approach to the interpretation of Rule 11 or to the selection of a sanction more appropriate than some other? ${ }^{74}$ Should we separately consider uncounselled pro se cases or prisoner cases? ${ }^{75}$

I do not know where such inquiries would lead us, although I do know that eliminating uncounselled pro se plaintiffs from the Task Force's data would not alter the conclusion of disproportionate impact in civil rights cases. The sanction rate for counselled plaintiffs in civil rights cases (45.5\%) is still far higher than the rate for counselled plaintiffs in non-civil rights cases $(8.7 \%)$ as well as for counselled plaintiffs as a whole (13.75\%). ${ }^{76}$ In any event, I find it hard to believe

${ }^{70}$ See id. For other reasons to expect continuing disproportionate impact on plaintiffs, see $i d$. at 67-68.

${ }^{71}$ See id. at 69 . The finding as to civil rights plaintiffs and plaintiffs in non-civil rights cases is statistically significant at a level of less than one percent.

72 See, e.g., Colburn v. Upper Darby Township, 838 F.2d 663, 666 (3d Cir. 1988) (requiring that section 1983 claims "contain a modicum of factual specificity"). See generally Marcus, The Revival of Fact Pleading Under the Federal Rules of Civil Procedure, 86 Colum. L. Rev. 433, 449-50 (1986).

73 Rule 8. General Rules of Pleading.

(a) Claims For Relief. A pleading which sets forth a claim for relief, whether an original claim, counterclaim, cross-claim, or third-party claim, shall contain (1) a short and plain statement of the grounds upon which the court's jurisdiction depends, unless the court already has jurisdiction and the claim needs no new grounds of jurisdiction to support it, (2) a short and plain statement of the claim showing that the pleader is entitled to relief, and (3) a demand for judgment for the relief the pleader seeks. Relief in the alternative or of several different types may be demanded.

Fed. R. Giv. P. 8(a).

74 See TASK FORCE REPORT, supra note 1, at 69-72, 100.

${ }^{75}$ See generally Note, Preserving Pro Se Representation in an Age of Rule 11 Sanctions, 65 TEX. L. ReV. 351 (1988).

${ }_{76}$ See TASK FORCE REPORT, supra note 1, at 71 . The finding as to counselled civil rights plaintiffs and counselled plaintiffs in non-civil rights cases is statistically 
that inquiries such as these would leave us satisfied with the status quo. To quote again from Professor Atiyah's inaugural lecture at Oxford:

I have said that perhaps one reason for the trend I have described is that it is easier to conceal a diversity of values when principles are jettisoned in favor of individualized justice. But how long can this process of concealment last? At a time when the ideal of egalitarianism rides as high as it does today, it is supremely ironical that we should at the same time be embracing discretion and rejecting principles; for this process must of necessity encourage and legitimize a greater inequality of treatment in the judicial process. The diversity of values underlying judicial decisions is thus concealed only by encouraging a departure from the ideal of equality. ${ }^{77}$

Most legal scholars experience tension between the advocacy they teach and the pursuit of knowledge to which they aspire. ${ }^{78}$ For legal scholars involved in the practical business of lawmaking, that tension must be acute. Even if empirical work offers the best help in mediating the tension felt by the scholar, ${ }^{79}$ the scholar/lawmaker usually does not have time. ${ }^{80}$ Still, I would argue, she should have the interest, and interest is not conveyed best by apologies for the status quo. If, as I have advocated, "[w]e need partnerships in determining how the field should be carved up for study, in studying it, and in implementing proposed reforms," to resources that could spell the difference. ${ }^{82}$ It should not be necessary,

significant at a level of less than one percent.

77 Atiyah, From Principles to Pragmatism: Changes in the Function of the Judicial Process and the Law, 65 IowA L. Rev. 1249, 1271 (1980).

${ }^{78}$ See Kronman, Foreword: Legal Scholarship and Moral Education, 90 YALE L.J. 955, 956 (1981).

${ }^{79}$ See Burbank, supra note 4, at 512; Rubin, supra note 4, at 1895-98.

${ }^{80} \mathrm{Cf}$. Weinstein, supra note 10 , at 1903 . I do not speak of mere professors. Their problem is not lack of "time to visit the courts and law firms to see what really is occurring." Id. It is, rather, lack of training and inclination. See Burbank, supra note 4, at 512-13; Rosenberg, supra note 6, at 2201-02, 2211.

81 Burbank, supra note 11, at 718. Both in his paper, see Carrington, Bogy, supra note 52, at 2076, and in colloquy at the Conference, Professor Carrington invoked the lack of qualifications of the present rulemakers, "a committee of technicians[,]. . . to consider the relative merits of competing political interests." Id. That is $m y$ point, but it simply means that we need to expand membership in the club, just as we need to expand its activities beyond the library. See Rosenberg, supra note 6, at 2201, 2211.

${ }^{82}$ For examples of such challenges, see Carrington, Bogy, supra note 52, at 2069; Hazard, supra note 57, at 2238.

Professor Carrington voices the suspicion that the group of "major problems of civil procedure that would yield more readily to multiple solutions" is "an empty set." Carrington, Bogy, supra note 52, at 2086. Yet, he acknowledges the propriety of "building into substantive enactments specific procedural provisions" when "necessary 
I respectfully suggest, for those who distrust the "concealment" of allegedly uniform and trans-substantive Federal Rules to show those with the power to affect legal development anything. We all should be looking for a better way and employing more than the power of ratiocination undisciplined by facts in the search. We need fewer mind experiments and more field experiments, procedural rules as well as procedural theories that are "based on experience."83 No one I know is suggesting a return to the forms of action or a wholesale rejection of trans-substantive procedure. ${ }^{84}$ Some of us, however, are suggesting that it is time both to face facts, in particular the fact that uniformity and trans-substantivity rhetoric are a sham ${ }^{85}$ and to find out the facts, in particular the facts about discretionary justice. A "veil of ignorance"88 may be an apt metaphor to describe federal rulemaking to date. ${ }^{87}$ It is

to effect enforcement of a substantive right." Id. (footnote omitted). Moreover, he suggests that "Ip]erhaps adjustment should [be] made as well for cases subject to a feeshifting statute." Id. at 2114-15 (footnote omitted). If such heresy is possible from one who espouses a "veil of ignorance" norm for rulemakers, id. at 2079, think of the possibilities if we troubled to find out how the Federal Rules really work. Until that time, however, challenges to identify where departures from trans-substantivity should occur are invitations to accept norms both of ignorance and of arrogance.

B3 Carrington, Bogy, supra note 52, at 2082.

84 See, e.g., Burbank, supra note 11, at 717 \& n.172; Subrin, supra note 22, at 2048-49. Of course, it suits the rhetorical purposes of defenders of the status quo to pretend otherwise. See, e.g., Hazard, supra note 57, at 2244; see also supra note 82.

ss Professor Carrington invokes a "principle of generalism," which he imputes to the Enabling Act, as the reason why the rulemakers have declined "to devise special pleading rules in cases arising under the civil liability provisions of the RICO Act." Carrington, Bogy, supra note 52, at 2080 (footnote omitted). This confuses the Enabling Act's requirement of uniform ("general") rules with a requirement, not fairly imputable to the Act, that Federal Rules also be trans-substantive. See supra text accompanying notes 51-55. More important, it neglects the fact that some courts already are imposing such "special pleading rules." See Burbank, supra note 11, at 716.

${ }_{86}$ Carrington, Bogy, supra note 52, at 2079; see also supra note 82.

87 See supra text accompanying notes 9-10. Benjamin Kaplan certainly did not share Professor Carrington's view concerning the appropriate posture of rulemakers or, for that matter, concerning the inviolability of the "principle of generalism." In 1967, as Reporter of the Advisory Committee, Kaplan wrote to Dean Acheson, the committee's chair, proposing a program of "basic research, both theoretic and empiric, with three interlocking phases or aspects. . .." Letter from Benjamin Kaplan to Dean Acheson, Esq. 3 (Mar. 2, 1967).

(b) The second phase would be an attempt to classify the various types of court-litigated matters by their intrinsic qualities and functions with a view to deciding whether the unitary court procedures now in vogue could be deliberately altered to accommodate better to the several types. The general advantages of a unitary or common procedure are evident, but they may be overborne by other considerations in certain classes of cases. As in (a) above, a study of this kind, while centering on procedure, could not remain totally procedural. The various classes of cases could be understood only if their substantive settings were appreciated, and this means an analysis of the relevant social and economic facts as well as the controlling material rules of law. 
not, I contend, an appropriate normative posture for the rulemakers of the future.

\section{Simplicity and Predictability}

Just as federal procedure is no longer, if it ever was, uniform, it is for the same reasons no longer, if it ever was, simple and predictable. ${ }^{88}$ A lawyer charting a procedural course can rely as safely on the Federal Rules of Civil Procedure as a sailor in the Bermuda Triangle can rely on a world atlas. ${ }^{89}$ Touted as a pocket bible, ${ }^{90}$ the Federal Rules now are best suited for an agnostic. Rule 11 is no exception.

As currently interpreted and implemented in many circuits, Rule 11 fails the historic tests of simplicity and predictability. "[L]ittle is less focused ... precise [or predictable than] what a judge or group of judges will think about a legal paper,"11 and in particular whether they will deem that paper legally frivolous. The costs of unpredictability-which in this case arguably results from judicial amendment ${ }^{92}$ - can include over-deterrence, which is the sort of chilling that concerned critics of the amended Rule at the time it was proposed and that also concerned the Advisory Committee. ${ }^{93}$ Moreover, probably because of preoccupation with a compensation perspective, or at least with expense-shifting as a sanction, Rule 11 jurisprudence is becoming complex. In some circuits, those seeking sanctions have been invested

It would be well to attempt to sort out litigated cases on a variety of bases besides the functional. For example, we have never pursued the full implications of a decision that small cases should not be able to claim the same refinements of procedure as big cases.

Id.

This letter is an important document in the history of modern American civil procedure, no less so because Kaplan's suggestion was not acted on. Accordingly, it is reproduced in full as an Appendix to this Article.

${ }_{88}$ The 1926 Senate Report observed: "Second, these general rules, if wisely made, would be a long step toward simplicity, a most desirable step in view of the chaotic and complicated condition which now exists." 1926 SENATE REPORT, supra note 18, at 2; see also Burbank, supra note 11, at 713, 715-16.

88 "If a group of mariners tired of studying their complicated charts should decide to throw them away and adopt more simple maps, they would not thereby do away with the air and water currents through which they must pass, or the icebergs or the reefs in their course." Hall, Uniform Law Procedure in Federal Courts, 33 W. VA. L.Q. 131, 134 (1927); see also Subrin, How Equity Conquered Common Law: The Federal Rules of Civil Procedure in Historical Perspective, 135 U. PA. L. REv. 909, 995 (1987); Subrin, supra note 21, at 1999, 2010.

so See, e.g., Hearings, supra note 19, at 4-5 (testimony of Attorney General Cummings); Subrin, supra note 21, at 2018.

91 TASK FORCE REPORT, supra note 1, at 21.

${ }^{92}$ See id. at 15.

${ }^{93}$ See supra note 49 and accompanying text. 
with duties, such as a formal duty of mitigation, ${ }^{94}$ as well as rights, ${ }^{95}$ and courts are turning to the jurisprudence of attorney's fees for guidance in imposing sanctions. ${ }^{86}$

Again, confining the abuses covered by Rule 11's "frivolousness clause" to pre-filing conduct should go a long way to solve the problem of unpredictability, as it should to advance the Rule's primary goal of deterrence.

Assume that a court finds that a lawyer did this much factual investigation or read these cases and that he/she should have pursued other factual leads or shepardized the cases consulted. The lawyer and others aware of the sanctioning decision have a basis for conforming their conduct to the prescribed standards in the future (assuming they have the resources to do so). An opinion imposing Rule 11 sanctions for failure to perform adequate factual investigation or legal research is thus, in our view, more likely to affect-behavior than one which sanctions a "wacky" theory . . . A corpus of such opinions is also more likely to yield consistent directions than a corpus of opinions finding, or finding other words for, frivolousness. ${ }^{97}$

On the other hand, taking seriously the duty to exercise discretion in selecting a sanction appropriate to the goal of deterrence, as opposed, for instance, to routine expense-shifting on an attorney's fee model, will not be a simple exercise for judges, which may help to explain why so many of them have shirked that duty. The difficulty has not to do with doctrine but with the agony of judgments about human conduct and what is likely to affect conduct, both of the individuals before the court and of others. But, again, that is a duty that the Rule imposes and, more important for present purposes, a reason it does so is evidently awareness of the differential impact of sanctions, whether viewed from the perspective of specific or general deterrence. ${ }^{88}$ From those perspectives, predictability is critical, and it cannot be achieved through routine, let alone uniform, resort to expense-shifting as a sanction under

24 See, e.g., Dubisky v. Owens, 849 F.2d 1034, 1037 (7th Cir. 1988).

${ }^{95}$ See supra text accompanying note 41.

${ }^{8 B}$ See, e.g., Napier v. Thirty or More Unidentified Fed. Agents, Employees, or Officers, 855 F.2d 1080, 1089-94 (3d Cir. 1988). But see Levin \& Sobel, Achieving Balance in the Developing Law of Sanctions, 36 GATH. U.L. Rev. 587, 598 (1987).

97 TASK FORCE REPORT, supra note 1, at 20-21 (citations omitted).

98 See supra text accompanying notes 49-50. 
Rule 11.

Faith in general deterrence must assume an actor who calculates the benefits and costs of behavior in advance. A monetary sanction onerous for its object may be mad money for our hypothetical actor. Unless he or she understands that the sanction was tailored to the circumstances of the violation and the sanctioned individual, it may be no deterrent at all, indeed quite the reverse. Worse, a monetary sanction easily absorbed by its object may be the life savings of our hypothetical actor. Unless he or she understands that sanction to be a considered response to the circumstances (and not, for instance, routine expense-shifting), the message received may be that litigation in federal court is not worth the risk. ${ }^{89}$

Thus, just as uniformity is a mirage in the implementation of Rule 11 , so is simplicity. Moreover and ironically, both mirages have been purchased at the price of predictability. The irony arises from the fact that the 1983 amiendments to the Federal Rules to a considerable extent gave up on the goals of uniformity and simplicity as any longer worth pursuing (except formally). ${ }^{100}$ As an instrument of deterrence, amended Rule 11 cannot be thought to have given up on predictability. Judges have done that.

\section{Adjudication ON THE MERITS}

The proponents of the Enabling Act ${ }^{101}$ and the drafters of the Federal Rules ${ }^{\mathbf{1 0 2}}$ shared the goal that procedure be the servant rather than the master of the substantive law. In implementation of that goal, the latter gave us a system in which pleading was to play a relatively minor, and not often dispositive, role in the definition or resolution of disputes brought to federal court. They expected party-initiated discovery to develop and refine disputes and the judicial discovery of pre-trial,

80 TASK FORCE REPORT, supra note 1, at 43-44.

${ }_{100}$ See supra text accompanying note 64 .

101 Fourth, it would make it more certain that if a plaintiff has a cause of action he would not be turned out of court upon a technicality and without a trial upon the very merits of the case; and, likewise, if the defendant had a just defense he would not be denied by any artifice of the opportunity to present it.

1926 SENATE REPORT, supra note 18 , at 2.

${ }_{102}$ See, e.g., Clark, The Handmaid of Justice, 23 WASH. U.L.Q. 297 (1938) (discussing the importance of keeping procedure "in its modest position as a handmaid"); see also Subrin, supra note 89, at 961-73 (discussing Clark's role in the development of the Federal Rules). 
including pre-trial conferences and decisions on motions for summary judgment, to separate the wheat from the chaff. ${ }^{103}$

It did not work out that way. One is reminded of an observation by proceduralists' favorite author, Charles Dickens: "Here are all kinds of employers wanting all sorts of servants, and all sorts of servants wanting all kinds of employers, and they never seem to come together." 104

Of course, some judges did not want, and some still do not want, any help. ${ }^{105}$ In any event, some of the amendments of the Eighties, and some that may be in prospect, seem to me not an example of "failing faith," ${ }^{108}$ but of a reawakening faith, albeit a different one. I speak of faith in the need for lawyers and clients to exercise some restraint in the consumption of resources, private and public, and in the need for federal trial judges to help them do so. Was that not the faith of the people responsible for original Rule $1,{ }^{107}$ Rule $11,{ }^{108}$ Rules $12(b)(6)^{109}$

103 See, e.g., Burbank, supra note 8, at 1476-77 \& n.74; Carrington, Bogy, supra note 52, at 2090-91; Marcus, Completing Equity's Conquest? Reflections on the Future of Trial Under the Federal Rules of Civil Procedure, 50 U. PITT. L. REv. 725, 739 (1989); Smith, Judge Charles E. Clark and the Federal Rules of Civil Procedure, 85 YALE L.J. 914, 918-19 (1976). For pre-trial as judicial discovery, see Sunderland, Discovery Before Trial Under the New Federal Rules, 15 TENN. L. REv. 737, 753-57 (1939).

104 C. Dickens, The Life and Adventures of Martin Chuzzlewit 641 (Penguin ed. 1968). And if you are not reminded, see J. BarTleTt, Familiar QuoTATIONS 495 (11th ed. 1939).

${ }^{105}$ See supra note 23.

108 Resnik, Failing Faith: Adjudicatory Procedure in Decline, 53 U. CHI. L. REv. 494 (1986). "Today, we should not be talking about the decline of adjudicatory procedure, except perhaps as one would at a wake." Burbank, supra note 8, at 1479 (footnote omitted).

${ }^{107}$ As originally promulgated by the Supreme Court, Rule 1 provided:

Rule 1. SCOPE of Rul.es. These rules govern the procedure in the district courts of the United States in all suits of a civil nature whether cognizable as cases at law or in equity, with the exceptions stated in Rule 81. They shall be construed to secure the just, speedy, and inexpensive determination of every action.

Rules of Civil Procedure for the District Courts of the United States, 308 U.S. 645, 663 (1938).

${ }^{108}$ As originally promulgated by the Supreme Court, Rule 11 provided:

Rule 11. Signing of Pleadings. Every pleading of a party represented by an attorney shall be signed by at least one attorney of record in his individual name, whose address shall be stated. A party who is not represented by an attorney shall sign his pleading and state his address. Except when otherwise specifically provided by rule or statute, pleadings need not be verified or accompanied by affidavit. The rule in equity that the averments of an answer under oath must be overcome by the testimony of two witnesses or of one witness sustained by corroborating circumstances is abolished. The signature of an attorney constitutes a certificate by him that he has read the pleading; that to the best of his knowledge, information, and belief there is good ground to support it; and that it is 


\section{and $12(\mathrm{c}),{ }^{110}$ Rule $16,{ }^{111}$ Rule $30(\mathrm{~b}),{ }^{112}$ and Rule $56 ?^{113}$}

not interposed for delay. If a pleading is not signed or is signed with intent to defeat the purpose of this rule, it may be stricken as sham and false and the action may proceed as though the pleading had not been served. For a wilful violation of this rule an attorney may be subjected to appropriate disciplinary action. Similar action may be taken if scandalous or indecent matter is inserted.

Id. at 676.

109 As originally promulgated by the Supreme Court, Rule $12(b)(6)$ provided:

Rule 12. Defenses and Objections - When and How Presented - By Pleading or Motion - Motion for Judgment on Pleadings.

(b)(6) failure to state a claim upon which relief can be granted.

Id. at 677 .

${ }^{110}$ As originally promulgated by the Supreme Court, Rule 12(c) provided:

(c) Motion For Judgment On The Pleadings. After the pleadings are closed but within such time as not to delay the trial, any party may move for judgment on the pleadings.

Id. at 678.

${ }^{111}$ As originally promulgated by the Supreme Court, Rule 16 provided:

Rule 16. Pre-Trial Procedure; Formulating Issues. In any action, the court may in its discretion direct the attorneys for the parties to appear before it for a conference to consider

(1) The simplification of the issues;

(2) The necessity or desirability of amendments to the pleadings;

(3) The possibility of obtaining admissions of fact and of documents which will avoid unnecessary proof;

(4) The limitation of the number of expert witnesses;

(5) The advisability of a preliminary reference of issues to a master for findings to be used as evidence when the trial is to be by jury;

(6) Such other matters as may aid in the disposition of the action.

The court shall make an order which recites the action taken at the conference, the amendments allowed to the pleadings, and the agreements made by the parties as to any of the matters considered, and which limits the issues for trial to those not disposed of by admissions or agreements of counsel; and such order when entered controls the subsequent course of the action, unless modified at the trial to prevent manifest injustice. The court in its discretion may establish by rule a pre-trial calendar on which actions may be placed for consideration as above provided and may either confine the calendar to jury actions or to non-jury actions or extend it to all actions.

Id. at 684 .

${ }_{112}$ As originally promulgated by the Supreme Court, Rule 30(b) provided:

Rule 30. Depositions Upon Oral Examination.

(b) Orders For The Protection Of Parties and Deponents. After notice is served for taking a deposition by oral examination, upon motion seasonably made by any party or by the person to be examined and upon notice and for good cause shown, the court in which the action is pending may make an order that the deposition shall not be taken, or that it may be taken only at some designated place other than that stated in the notice, or that it may be taken only on written interrogatories, or that certain matters shall not be inquired into, or that the scope of the examination 
To be sure, the original rulemakers missed some opportunities to take

shall be limited to certain matters, or that the examination shall be held with no one present except the parties to the action and their officers or counsel, or that after being sealed the deposition shall be opened only by order of the court, or that secret processes, developments, or research need not be disclosed, or that the parties shall simultaneously file specified documents or information enclosed in sealed envelopes to be opened as directed by the court; or the court may make any other order which justice requires to protect the party or witness from annoyance, embarrassment, or oppression.

Id. at 701.

${ }_{113}$ As originally promulgated by the Supreme Courts, Rule 56 provided:

Rule 56. Summary Judgment.

(a) For Claimant. A party seeking to recover upon a claim, counterclaim, or cross-claim or to obtain a declaratory judgment may, at any time after the pleading in answer thereto has been served, move with or without supporting affidavits for a summary judgment in his favor upon all or any part thereof.

(b) For Defending Party. A party against whom a claim, counterclaim, or cross-claim is asserted or a declaratory judgment is sought may, at any time, move with or without supporting affidavits for a summary judgment in his favor as to all or any part thereof.

(c) Motion And Proceedings Thereon. The motion shall be served at least 10 days before the time specified for the hearing. The adverse party prior to the day of hearing may serve opposing affidavits. The judgment sought shall be rendered forthwith if the pleadings, depositions, and admissions on file, together with the affidavits, if any, show that, except as to the amount of damages, there is no genuine issue as to any material fact and that the moving party is entitled to a judgment as a matter of law.

(d) Case Not Fully adjudicated On Motion. If on motion under this rule judgment is not rendered upon the whole case or for all the relief asked and a trial is necessary, the court at the hearing of the motion, by examining the pleadings and the evidence before it and by interrogating counsel, shall if practicable ascertain what material facts exist without substantial controversy and what material facts are actually and in good faith controverted. It shall thereupon make an order specifying the facts that appear without substantial controversy, including the extent to which the amount of damages or other relief is not in controversy, and directing such further proceedings in the action as are just. Upon the trial of the action the facts so specified shall be deemed established, and the trial shall be conducted accordingly.

(e) Form Of Affidavits; Further Testimony. Supporting and opposing affidavits shall be made on personal knowledge, shall set forth such facts as would be admissible in evidence, and shall show affirmatively that the affiant is competent to testify to the matters stated therein. Sworn or certified copies of all papers or parts thereof referred to in an affidavit shall be attached thereto or served therewith. The court may permit affidavits to be supplemented or opposed by depositions or by further affidavits.

(f) When Affidavits ARE Unavailable. Should it appear from the affidavits of a party opposing the motion that he cannot for reasons stated present by affidavit facts essential to justify his opposition, the court may refuse the application for judgment or may order a continuance to permit affidavits to be obtained or depositions to be taken or discovery to 
justice out of the eye of the beholder, as they surely underestimated the willingness or ability of federal judges to resist the combined centrifugal forces of lawyers in search of a claim or a fee and of the rhetoric of reform. ${ }^{114}$ But the original Federal Rules were transformed in the courts just as surely as amended Rule 11 has been transformed. In the latter case, what can and, I believe, should be regarded as a corrective or mid-course adjustment instead is regarded by some as an instrument for a change of course. The result is that one reform strategy, encouraging judges to manage litigation, is at risk of confusion with another, encouraging people to avoid litigation. ${ }^{115}$

How else is one to view the recent pronouncement by the Court of Appeals for the Seventh Circuit that "Rule 11 is a fee-shifting statute"?116 Of course it is nothing of the sort, but the theoretical literature indicates that fee-shifting can have a disproportionate impact on the risk averse. ${ }^{117}$ Moreover, we no longer need simply to speculate about the disproportionate impact of Rule 11 on plaintiffs (or their lawyers) and on civil rights plaintiffs (or their lawyers), although, as I have indicated, we need to ask, and pursue the answers to, many more questions raised by that information. ${ }^{118}$ Theory is an irresponsible basis for lawmaking about something as important as access to court, and it is especially irresponsible when the lawmaking involves judicial amendment of

be had or may make such other order as is just.

(g) AfFidavits MADE IN BAD FaITH. Should it appear to the satisfaction of the court at any time that any of the affidavits presented pursuant to this rule are presented in bad faith or solely for the purpose of delay, the court shall forthwith order the party employing them to pay to the other party the amount of the reasonable expenses which the filing of the affidavits caused him to incur, including reasonable attorney's fees, and any offending party or attorney may be adjudged guilty of contempt.

Id. at $734-35$.

114 See Burbank, supra note 8 , at 1477-78.

115 Two [reform] strategies have dominated recent efforts of the rulemakers and debate in the literature. One is to enhance the power of trial judges to manage litigation. Another is to enhance incentives for people to avoid litigation. Both represent steps in the flight from law.

Burbank, supra note 11, at 716 (footnotes omitted).

116 Hays v. Sony Corp., 847 F.2d 412, 419 (7th Gir. 1988).

117 See, e.g., Rowe, Predicting the Effects of Attorney Fee Shifting, 47 LAw \& Contemp. Probs. 139, 164-70 (1984); see also Burbank, Proposals to Amend Rule 68 -Time to Abandon Ship, 19 U. MICH. J.L. REF. 425, 436, 439 (1986) (impact on risk-averse of proposals to deny attorney's fees to, or impose them on, those who refuse offers of settlement).

For the results of an empirical study tending to confirm the disproportionate impact of fee-shifting on the risk-averse, see Rowe \& Vidmar, Empirical Research on Offers of Settlement: A Preliminary Report (forthcoming in 1988 LAw \& CoNTEMP. Probs.).

118 See supra text accompanying notes 65-87. 
a Rule that, in part because of access concerns, only barely escaped the bright light of the democratic process. ${ }^{118}$

How else is one to view the blessing given by the same court to a Rule 11 sanction imposed in a civil rights case "for failing to include [in a complaint] factual allegations that would indicate the claim might have merit"?120 The court observed that "[i]f the file contains unprivileged information that would rectify the factual deficiencies we have noted, plaintiff's counsel's failure to include those facts warrants the imposition of sanctions."121 Subsequent opinions by other panels of that court have recognized the error of engrafting Rule 11 on Rule $8,{ }^{122}$ but they also have imposed another requirement: to wit, that a court impose sanctions even if it can think of a "good faith argument for the extension, modification or reversal of existing law" but the attorney or pro se litigant did not in fact make that argument. ${ }^{123}$ The requirement may make sense so long as the Rule is interpreted to reach only prefiling conduct and representations about that conduct. It does not, however, clearly make sense under a product approach-which assesses the frivolousness of filed papers-at least one driven by concern for the recoupment by litigants of "unjustified" costs. ${ }^{124}$

A conduct approach to amended Rule 11 should help to unravel

118 On July 26, the House passed a bill that would have delayed the effective date of the 1983 amendments until December 1, 1983. See H.R. 3497, 98th Cong., 1st Sess., 129 Cong. Rec. H5560-62 (daily ed. July 26, 1983). In the Senate, the bill was held at the desk until the close of business on Friday, July 29, see 129 CoNG. REc S10,912 (daily ed. July 26,1983), and on the latter date it was referred to the Senate Judiciary Committee. See 129 CoNG. REC. S11,169 (daily ed. July 29, 1983). The latter action doomed the effort to delay the effective date because, in the absence of legislation, the proposed Rules would go into effect, as they did, on Monday, August 1, 1983. See 129 ConG. Rec. H5560 (daily ed. July 26, 1983).

Professor Miller, reporter to the Advisory Committee for the 1983 amendments, observed that those rules "by the thinnest hair you can think of became effective on August 1, 1983." He continued: "It was one of those death-defying cliff-hangers because a bill to delay their effectiveness was sitting in the well of the Senate on the appropriate morning, but no one hauled it out." A. Miller, supra note 5, at 1.

${ }_{120}$ Rodgers v. Lincoln Towing Serv., 771 F.2d 194, 206 (7th Cir. 1985).

121 Id.

122 See, e.g., Frantz v. United States Powerlifting Fed'n, 836 F.2d 1063, 1067-68 (7th Cir. 1987) ("Rule 11 requires not that counsel plead facts but that counsel know facts after conducting a reasonable investigation-and then only enough to make it reasonable to press litigation to the point of seeking discovery.")

${ }^{123}$ See, e.g., In re Ronco, Inc., 838 F.2d 212, 218 (7th Cir. 1988).

124 There is, however, no clear dichotomy between conduct and product approaches. See TASK FORCE REPORT, supra note 1, at 20, 24-25. In the Seventh Circuit, for example, perceived deficiencies in either product or pre-filing conduct can lead to Rule 11 sanctions. See, e.g., Frantz, 836 F.2d at 1065. Moreover, product may be used as a basis for inference about conduct. See Brown v. Federation of State Med. Bds., 830 F.2d 1429, 1436 (7th Cir. 1987). The message seems to be, in the words of a television commercial, "one way or another, we're going to get you." 
the question of sanctions from questions on the merits. But even assuming such an approach, we should be concerned about the impact of the amended Rule on other Federal Rules and phases of litigation that implicate the willingness and ability of people to seek redress for their grievances in federal court and to have those grievances fairly considered.

Professors James and Hazard have observed:

The incidence of the strike suit has led to proposals for tightening the pleading rules. There has not been much support for returning to code pleading, and probably interests associated with plaintiffs' causes are strong enough to block such a change. However, something approximating that result may be in progress indirectly. Rule 11 of the federal rules was amended in 1983 to require that all motions and pleadings be based on the subscribing attorney's "belief formed after reasonable inquiry [that] it is well grounded in fact . . . ." As some decisions suggest, this language could be administered to require the pleading to show that it is "well grounded in fact." It is difficult to see how such a requirement could be complied with except by alleging the factual grounds of the claim. This is a move in the direction of code pleading. ${ }^{125}$

More recently, the Harvard Law Review has published student work treating the issues in considerable depth. ${ }^{126}$ The author attributes the liberal pleading and discovery provisions of the original Federal Rules to the realists' rejection of formalism, their perception of the indeterminacy of legal doctrine, and their faith in the power of facts. The author sees in amended Rule 11, at least as interpreted, a threat to both this philosophy and to the Rules we inherited in 1938, and argues that Rule 11 should be interpreted in such a way as to preserve both.

Having asserted at the outset that the 1983 amendments to Rule 11 "alter the balance struck by the original Federal Rules scheme between open access to court and efficient disposition of claims," author later (much later) acknowledges that they need not be read to do so and indeed that the Advisory Committee took some pains to minimize that risk. ${ }^{128}$ Similarly, the author equates the amended Rule's re-

\footnotetext{
(footnotes omitted).

${ }^{128}$ See generally Note, Plausible Pleadings: Developing Standards for Rule 11 Sanctions, 100 HaRv. L. Rev. 630 (1987).

${ }^{127}$ Id. at 630.

${ }^{128}$ See id. at 647-51.
}

${ }^{125}$ F. James \& G. Hazard, Crvil Procedure $§ 3.11$, at 154-55 (3d ed. 1985) 
quirement of a reasonable factual inquiry with a requirement of pleading facts, burying in a footnote the assertion that the former is "tantamount" to the latter because, in the absence of a hearing, lawyers "are under pressure to allege whatever factual support is available to them."128

Again, the author posits a dichotomy (in the Rule, not just the decisions interpreting it) between product and conduct, one that is artificial and appears designed to further the author's thesis rather than to "clarify."130 Finally, the author's assertion that "[i]n the absence of an explicit mandate to abandon the commitments of legal realism by changing the standard of pleading and the role of other pretrial procedural mechanisms, rule 11 must be read consistently with both its own terms and the established procedural scheme"131 is simply and extraordinarily naive.

Withal, the Note should stimulate thinking about some important issues. We need not resolve whether those responsible for the original Federal Rules embraced the realist faith, and the evidence does not support the notion that they intended to permit the filing of a complaint on a wish and a prayer. ${ }^{132}$ The Enabling Act empowers the Supreme Court to change the Rules and to do so according to whatever procedural philosophy appeals to the Justices. Whether the rulemakers intended to "alter the balance" in the 1983 amendments is essentially a factual inquiry on which the Advisory Committee Notes shed light, and one's conclusion on that question is appropriately subject to normative debate.

The requirement of a reasonable factual inquiry in amended Rule 11 need not be interpreted as inconsistent with the liberal pleading rules and, because those rules were not themselves amended in 1983, it probably should not be. Nor need the requirement be interpreted as inconsistent with the discovery rules, although in evaluating the latter assertion, it may be important to take account of the 1980 and 1983 amendments to the discovery rules. ${ }^{133}$ "Discovery was hardly intended to enable a learned profession to perform its functions either without wits or on wits borrowed from the adversary."134 There is no reason to

128 Id. at 635 n.25.

130 See id. at 642 n.64.

131 Id. at 648.

132 See C. Clark, Code Pleading 146-48 (2d ed. 1947); F. James \& G. HazARD, supra note $125, \S 3.11$, at 152; Rosenberg, supra note 6, 2205-07; infra text accompanying notes $135 \& 150$.

${ }_{133}$ See FED. R. Crv. P. 26(f) (added in 1980); FED. R. Crv. P. 26(b)(1) \& 26(g) (amended and added, respectively, in 1983).

${ }^{134}$ Hickman v. Taylor, 329 U.S. 495, 516 (1947) (Jackson, J., concurring). 
believe that the original Advisory Committee intended to relieve litigants of responsibility to make any pre-discovery inquiry into the facts; indeed, original Rule 11 seemingly contradicts such a notion. ${ }^{\mathbf{1 3 5}}$

Some courts, in fact, are imposing sanctions without an opportunity to be heard on the question of the reasonableness of the pre-filing factual inquiry. ${ }^{136}$ The problem can and should be corrected on review by a higher court, recognizing the political pressures under which the Advisory Committee operated and the practical pressures under which federal trial courts operate. ${ }^{\mathbf{1 3 7}}$

Lurking beneath the surface of the student author's arguments about the factual component of the Rule 11 certification is the concern that the new requirement will have a disproportionately adverse effect on litigants (namely plaintiffs) with limited resources. ${ }^{138}$ A formal response to that concern might invoke the Supreme Court's dismissal of a similar argument made in connection with the discovery rules. ${ }^{139}$ But

135 For the text of original Rule 11, see supra note 108.

Rule 11 deals with the Signing of Pleadings. There, if you read down through it, you will see that, in general, verification, or taking of oath, is not required, but, on the other hand, the signing by the attorney is a certificate of substantially the same effect, perhaps a little stronger than any mere formal oath would be.

Proceedings of the Cleveland Institute on Federal Rules 236 (1938) [hereinafter Clevveland InSTITUTE] (statement of Charles E. Clark); see also ProceEdINGS OF THE WASHINGTON, D.C. INSTITUTE ON FEDERAL Rules 52 (1939) [hereinafter WASHINGTON D.C. INSTITUTE] ("[T]he signature of the lawyer, carrying with it certain responsibilities, is much more important and worthwhile than an oath . . .."). In this age of sanctions, we may forget a distinction between the duties imposed by a rule and the consequences of failing to perform those duties. Clark was very much aware of that distinction in connection with Rule 11, which provided for attorney discipline only in the event of "wilful violation." See WASHINGTON D.C. INSTITUTE, supra, at 72; see also Proceedings of THE New York SyMPosium on Federal RULes 298 (1939) (general denials to partially incorrect averments contravene the spirit of Rule 11).

${ }^{136}$ See United States v. Childers, 846 F.2d 74 (4th Cir. 1988) (text in WESTLAW and LEXIS); TASK FORCE REPORT, supra note 1, at 25-29.

$187-90$

${ }^{137}$ See Burbank, supra note 7, at 1009-10 \& n.60; infra text accompanying notes

${ }^{138}$ See Note, supra note 126 , at 642-43.

139 As the Supreme Court said in Hickman v. Taylor, 329 U.S. 495 (1947):

But framing the problem in terms of assisting individual plaintiffs in their suits against corporate defendants is unsatisfactory. Discovery concededly may work to the disadvantage as well as to the advantage of individual plaintiffs. Discovery, in other words, is not a one-way proposition. It is available in all types of cases at the behest of any party, individual or corporate, plaintiff or defendant. The problem thus far transcends the situation confronting this petitioner. And we must view the problem in light of the limitless situations where the particular kind of discovery sought by petitioner might be used.

Id. at 507. 
the Court's dismissal was itself a formal response, necessitated by the trans-substantive structure of the Federal Rules and the danger of opening up the possibility of differential substantive impact. ${ }^{140}$ Awareness of the same imperatives may explain the Advisory Committee's failure to address concern about differential impact on the poor after it was raised in response to the 1981 proposal to amend Rule 11. ${ }^{141}$ The Third Circuit Task Force similarly does not address the question at any length, but it does encourage others to pursue it. ${ }^{142}$

One avenue of escape from this dilemma would be to consider a client's or a lawyer's resources in judging the reasonableness of a prefiling factual inquiry. An advantage of a conduct approach to Rule 11 is that it brings to the surface resource questions that tend to be buried by a product approach. ${ }^{143}$ Yet, once recognized, the relevance of finances presumably would have to be extended to the legal component of the certification. ${ }^{144}$ Moreover, before proceeding down this avenue, one would want very carefully to consider both the realities and the doctrinal framework of litigation finance. From that perspective, one might conclude that the problem, if it exists, should be solved directly (that is, by providing adequate funding of legal aid) and that otherwise lawyers should not be permitted to hedge their bets when accepting cases on a contingent fee basis or in the expectation of recovering fees under an exception to the American Rule. ${ }^{145}$

140 It is interesting but not surprising, see supra text accompanying notes 51-63, 77-87, to find Professor Carrington invoking this passage. See Carrington, Bogy, supra note 52 , at 2080 .

${ }^{141}$ See Advisory Committee on Civil Rules, Analysis of Comments Regarding Committee's Proposed Amendments to Rules 7 and 11, at 2-3 (Dec. 1981) [hereinafter Analysis of Comments] (copy available from author).

${ }_{142}$ See TASK ForCE REPORT, supra note 1, at 72.

143 See id.

144 See Singh v. Curry, 122 F.R.D. 27, 29-30 (N.D. Ill. 1988) (refusing to impose Rule 11 sanctions for failure to find very recent appellate cases available, if at all, only on computer or through advance sheets). Compare Hays v. Sony Corp., 847 F.2d 412, 419 (7th Cir. 1988) (Rule 11 has an objective standard and makes no allowance for the particular circumstances of an attorney) with Muthig v. Brant Point Nantucket, Inc., 838 F.2d 600, 605 (1st Cir. 1988) (considering as possible mitigating circumstances "against a stringent application of Rule 11" whether attorney is an "understaffed sole practitioner seeking to aid a client who has been hurt by the defendant but who is uncertain about the exact legal vehicle for redress . . . [or] trying to make new law" rather than "associated with a major law firm with all the attendant resources").

${ }_{145}$ But cf. Cappelletti \& Garth, A Comparative Conclusion, in XVI INTERnAtional Encyclopedia of Comparative Law 6-447 to 6-450 (M. Cappelletti ed. 1984).

The adversary system in its pure form assumes that each side will be represented equally, therefore necessitating no intervention by the court. Consistent with this view, it can be asserted that high quality legal aid is the only way to redress inequalities in litigation resources. Equal access to lawyers should thus lead to the adversary system at its best. The problem 
The Note also raises concerns about amended Rule 11's requirement of a reasonable legal inquiry. Here again, one need not accept the assertion that the original Federal Rules were animated by an unadulterated realist view of the factual contingency of law. On the other hand, as the author observes, there is an inescapable connection between the factual and legal components of the Rule 11 certification. ${ }^{148}$ Requiring a plaintiff or her attorney to certify after reasonable inquiry that, "to the best of [her] knowledge . ..." a complaint is wellgrounded in fact necessarily imports a judgment about the relevance of facts under a legal theory. It also may be true, as the author asserts, that " $\mathrm{t}$ ]o meet the liberal standard of pleading, a complaint need not have settled on a legal theory, nor even have articulated one, as long as the complaint identifies the transaction or occurrence upon which its claims are based."147 The crucial question, however, is whether the plaintiff's lawyer (or a pro se plaintiff) must have conceived a legal theory before filing, even if it is not laid out in the paper filed. The concerns arising from an affirmative answer to that question are not only that it may be inconsistent with the power of federal judges to "decide cases on the basis of their own research and analysis of the issues rather than relying on any interpretation advocated by the lawyer." 148 Because, for most mortals, creativity is a factually contingent enterprise, the process of extending, modifying, or (to a lesser extent) reversing existing law is at the mercy of the available facts. In other words, the existence of liberal discovery has played an important role in legal development over the past fifty years. ${ }^{149}$

As to the first concern-the role of federal judges in preserving possibly meritorious cases against early dismissal-it seems no more likely that the framers of the original Federal Rules contemplated a plaintiff without a legal theory than they did a plaintiff without facts. ${ }^{150}$ Moreover, the Advisory Committee Note to amended Rule 11 quite clearly contemplates a preconceived legal theory. ${ }^{151}$ On the other hand, Supreme Court decisions concerning dismissals under Rule

is that, outside of perhaps SWEDEN, no legal aid system commits enough resources to ensure that all those who cannot afford a lawyer will have access to one.

Id. at 6-448.

${ }^{146}$ See Note, supra note 126 , at 637.

147 Id. at 641 (footnotes omitted) (emphasis added).

${ }^{148} \mathrm{Id}$. at 641 n.62.

148 See Friedenthal, A Divided Supreme Court Adopts Discovery Amendments to the Federal Rules of Civil Procedure, 69 Calif. L. Rev. 806, 818-19 (1981).

100 See, e.g., CleVELAND INSTITUTE, supra note 135, at 226-27; Rosenberg, supra note 6, at 2205-07.

151 See FED. R. Civ. P. 11 advisory committee note. 
12(b)(6) certainly permit, if they do not require, federal trial judges to exercise independent judgment about the legal viability of a complaint, particularly one filed by a pro se plaintiff. ${ }^{162}$ It seems unlikely that many federal judges would impose sanctions for filing a complaint that had been sustained against a 12(b)(6) motion on the ground that the judge had to come up with the theory independent of the efforts of counsel. ${ }^{153}$ A more realistic risk associated with this tension is that some federal judges will see in amended Rule 11 positive direction not to exercise such independent judgment, or at least an excuse for not doing so. The result would be managerial judging in only one direction. ${ }^{154}$

The second concern-the role of discovery in legal development-is related to the first in that there is no logical entailment of the 1983 amendments that should affect the number of cases proceeding to discovery. Here, however, one should add to the risk discussed above the risk that judges will see in the 1980 and 1983 amendments to the discovery rules additional counterweights to arguments predicated on the alleged intent behind the original Rules or experience under them. That might be unfortunate. The Advisory Committee Note to amended Rule 26(b) cautions that "the court must be careful not to deprive a party of discovery that is reasonably necessary to afford a fair opportunity to develop and prepare the case." ${ }^{155}$ The Note to Rule 26(g) states that the certification duty imposed by that Rule "is not meant to discourage or restrict necessary and legitimate discovery."156 Perhaps, however, our notions of fairness or of "legitimate discovery" have changed. ${ }^{157}$

162 See Hospital Bldg. Co. v. Trustees of Rex Hosp., 425 U.S. 738, 746 (1976); Haines v. Kerner, 404 U.S. 519, 520-21 (1972); Conley v. Gibson, 355 U.S. 41, 45-46 (1957).

${ }_{103}$ But see supra text accompanying notes 123-24.

154 Delays at the expense of one or both parties, unequal advocacy, and unintentional lapses in the development of crucial facts, all contribute to unjust results and inappropriate settlements. If our goal is more than procedural equality in the abstract-an equal freedom to control the proceedings - we should be hesitant to discard the potential advantages of judges who depart somewhat from the traditional passive role. One might suggest, however, that litigation involving unequal parties belongs in alternatives to the courts; the court ideal must be preserved intact. That question, however, then leads to a different kind of concern. For whom do our ordinary courts exist?

Cappelletti \& Garth, supra note 145, at 6-449.

${ }_{185}$ FED. R. CIV. P. 26(b) advisory committee note.

${ }_{158}$ FED. R. GIv. P. 26(g) advisory committee note.

157 On fairness, see Newman, Rethinking Fairness: Perspectives on the Litigation Process, 94 YALE L.J. 1643, 1644-46 (1985). But see Burbank, supra note 8, at 148283. On "legitimate discovery," see Friedenthal, supra note 149, at 815-19; Rosenberg, 


\section{EFFICIENCY}

Rule 1 speaks of "the just, speedy, and inexpensive determination of every action."158 The concern that too much federal litigation was protracted and expensive, with consequences for litigants, prospective litigants, and the courts, was a major animating force behind the 1980 and 1983 amendments to the Federal Rules of Givil Procedure. ${ }^{158}$ In amending Rule 11, the rulemakers hoped that it would serve "as a healthy deterrent against costly meritless maneuvers."160 They also were concerned, however, about arguments that any benefits in that regard would be offset, if not swamped, by the costs of litigating Rule 11 issues, so-called satellite litigation. ${ }^{\mathbf{1 0 1}}$ In addition, they could not ignore critics who, refusing to confine the cost-benefit calculus to the realm of judicial administration, claimed that the costs of the Rule would include chilling zealous but legitimate advocacy, with consequences for legal development, and poisoning relationships between lawyers and clients, lawyers and lawyers, and lawyers and judges. ${ }^{\mathbf{1 6 2}}$

The debate that attended the proposal to amend Rule 11 in 1981 continues today. Thus far, it too often has been a debate characterized by "cosmic anecdote[s]"163 on the one hand and confident assertions on the other, both largely uninformed by data, except perhaps a selective reading of published opinions. Yet, even viewed in gross, published opinions are not a reliable index of what is happening in district courts, at least in the Third Circuit. Only $9.1 \%$ of the decisions on Rule 11

Foreword, 69 CALIF. L. REv. 647, 651 (1981) Subrin, supra note 21, at 2023-26; Weinstein, supra note 10, at 1915-16.

158 FED. R. Civ. P. 1. This was one of the "selling points" of the Rules Enabling Act. See 1926 SENATE REPORT, supra note 18, at 2 ("Third, [the Federal Rules] would tend toward the speedier and more intelligent disposition of the issues presented in law actions and toward a reduction in the expense of litigation").

158 See A. MrLler, supra note 5, at 1-11. Judge Patrick Higginbotham cautions:

A more efficient process is always an important goal of procedural rules.

But failing to identify the policy choices that attend procedural alternatives skews the decision-making process by understating the stakes and inviting a judicial exercise of legislative function. Broad jurisdictional rules, of course, carry a heavy political charge, but it is not hard to find less explosive examples of ignored social choice in rule changes.

Higginbotham, Playing by the Rules (Book Review), 75 A.B.A. J. 118, 119 (1989).

${ }_{160}$ Memorandum from Hon. Walter R. Mansfield to Hon. Edward T. Gignoux, 97 F.R.D. 190, 192 (1983).

${ }_{161}$ See FED. R. Grv. P. 11 advisory committee note; Burbank, supra note 7, at 1009-10 \& n.60.

162 See TASK Force RePort, supra note 1, at 83-87; Analysis of Comments, supra note 141, at 2-3; supra note 49 and accompanying text. The Advisory Committee apparently did ignore, in the sense that it did not address, concerns about additional barriers to the poor. See supra text accompanying notes 141-42.

${ }^{163}$ A. Miller, supra note 5, at 11. 
issues in the period June 30, 1987 through July 1, 1988 (during which the Third Circuit Task Force collected data) have been, or are scheduled to be, published in Federal Supplement or Federal Rules Decisions. Only $39.1 \%$ of those decisions are available on Lexis. Moreover, although the published decisions would suggest that sanctions are imposed in $40 \%$ of the cases in which a Rule 11 issue is raised (by motion or sua sponte), the actual percentage for the survey period was $19.8 \%{ }^{164}$

From its questionnaires, surveys, and interviews, the Task Force found evidence of widespread effects on the pre-filing conduct of lawyers practicing in the Third Circuit, such as enhanced pre-filing factual and legal inquiry, of the sort desired by the rulemakers, as well as evidence of other benefits, including effects on settlement or voluntary dismissal and the perceived effectiveness of warnings by judges issuing them. ${ }^{165}$

As to the directly associated costs of these benefits, the Task Force found that Rule 11 motions are not routine in the Third Circuit. In a one-year period, we could identify such motions in only approximately one half of one percent of all civil cases. ${ }^{166}$ Moreover, on the basis of (1) data gathered from interviews with lawyers relating to the time devoted to the Rule 11 issues and to the cost of litigating those issues, (2) data on the procedures used in resolving, and the modes of disposition of, Rule 11 issues by trial judges, and (3) data on the costs of appeals, the Task Force concluded that the directly associated costs were not, at least during the survey period, clearly incommensurate with the probable benefits. ${ }^{167}$

The Task Force also concluded that, although some other costs of Rule 11 are not presently a source of serious concern in the Third Circuit, ${ }^{188}$ certain collateral consequences of the Rule, such as its impact on the cost or availability of professional liability insurance, are imperfectly understood and may well increase significantly in the future. ${ }^{168}$ For that reason alone, the Task Force is concerned that, even if the net of costs and benefits in the Third Circuit were clear today, which it is not, a similar Task Force might reach a different conclusion in three years. ${ }^{170}$

164 See TASK FORCE REPORT, supra note 1, at 45, 59.

${ }^{165}$ See id. at 75-77. The ambiguity of some of these findings is discussed in id. at

76, 84. See also infra text accompanying notes 197-98.

${ }_{166}$ See TASK ForCE REPORT, supra note 1, at 60.

187 See id. at $77-83,95$.

168 See id. at 83-88.

168 See id. at 88-92.

170 See id. at 96. 
If the net of benefits and costs of amended Rule 11 is unclear today in the Third Circuit, where Rule 11 motions are not routine, where the prevailing attitude toward sanctions in general is hardly one of embrace, ${ }^{171}$ and where the Court of Appeals has issued a series of opinions designed to ensure that the Rule is "reserved for only exceptional circumstances,"172 what of other circuits with different attitudes towards and approaches to sanctions and Rule 11? We lack reliable empirical data, which is why the Task Force's first recommendation is that "[a] similar study should be undertaken in a circuit with a different reputation regarding, and (as evidenced by case law) different normative perspectives on, Rule 11 sanctions."173

It is possible, however, to speculate what such a study might find, or at least to formulate hypotheses for testing, based on a consideration of alternative normative perspectives on Rule $11 .{ }^{174}$ As an example, my personal speculation is that such a study in the Seventh Circuit might confirm the worst fears of Rule 11's critics. This is a Gircuit, after all, whose district courts have been encouraged to enforce Rule 11 "to the hilt"175 and required to explain the denial of Rule 11 motions that are judged "serious" according to, among other things, the amount of money they seek. ${ }^{176}$ It is, moreover, a Circuit whose lawyers are encouraged, and whose district judges are required, to test legal papers for frivolousness, all in furtherance of the supposed goal of compensation for the imposition of "unjustified" costs. ${ }^{177}$ It is, finally, a Circuit that encourages appeals from the denial of Rule 11 motions, in part because the judges have not been able to agree on the standard of appellate review. ${ }^{178}$

171 See ABa Section of Litigation, Sanctions: Rule 11 and Other PowERS 50-52 (2d ed. 1988); TASK FORCE REPORT, supra note 1, at 25, 39, 45.

${ }^{172}$ Morristown Daily Record, Inc. v. Graphic Communications Union, 832 F.2d 31, 32 n.1 (3d Cir. 1987); Teamsters Local Union No. 430 v. Cement Express, Inc., 841 F.2d 66, 68 (3d Cir.), cert. denied, 109 S. Ct. 128 (1988); see also Gaiardo v. Ethyl Corp., 835 F.2d 479, 483 (3d Cir. 1987).

${ }^{173}$ TASK FORCE REPORT, supra note 1, at 96.

174 See Rubin, supra note 4, at 1891-1904.

175 Dreis \& Krump Mfg. Co. v. International Ass'n of Machinists, 802 F.2d 247, 255 (7th Cir. 1986).

${ }_{176}$ See Szabo Food Serv., Inc. v. Canteen Corp., 823 F.2d 1073, 1084 (7th Cir. 1987), cert. dismissed, 108 S. Ct. 1101 (1988); see also Tarkowski v. County of Lake, 775 F.2d 173, 176 (7th Cir. 1985). (Rule 11 and $\&$ 1988). But see Wojan v. General Motors Corp., 851 F.2d 969, 974 (7th Cir. 1988).

177 See supra text accompanying note 39.

${ }^{178}$ See, e.g., FDIC v. Tekfen Constr. \& Installation Co., 847 F.2d 440, 443 (7th Cir. 1988) (recognizing that "[o]ur own opinions have not always been models of clarity" on the standard of review in Rule 11 cases). After this paper was delivered, the Court of Appeals ordered rehearing en banc of an appeal for the purpose of determining "which standard should be applied in reviewing [Rule 11] sanctions imposed by the 
The combination of a product approach to the interpretation of Rule 11's certification standard, a compensatory perspective, and judicial embrace of sanctions should provide a powerful incentive for lawyers and clients to seek such sanctions when they prevail on the merits. ${ }^{179}$ If, as the Court of Appeals for the Ninth Circuit has opined, "[i]n even a close case, . . . it [is] extremely unlikely that a judge, who has already decided that the law is not as a lawyer argued it, will also decide that the loser's position was warranted by existing law[,]"180 it is much more unlikely that the winner will so view the loser's position. ${ }^{\mathbf{1 8 1}}$ In the Seventh Circuit, the winner's lawyer knows that judges are not to preserve the loser from sanctions by themselves imagining an argument for "the extension, modification or reversal of existing law."182 More important, the lawyer knows that if sanctions are imposed, they are likely to be expenses, including attorney's fees. ${ }^{183}$ As a result, in many cases ${ }^{\mathbf{1 8 4}}$ the stakes are the entire bill for defending a lawsuit. In such a climate, the winner's lawyer should ask whether it would be professionally responsible not to recommend filing a Rule 11 motion. ${ }^{185}$ Perhaps district courts are sending signals in conflict with those sent by the vigorous proponents of fee-shifting sanctions on the court of appeals, but to what effect in light of the incentives to appeal a denial of sanctions? ${ }^{188}$

district court." Mars Steel Corp. v. Continental Illinois Nat'l Bank \& Trust, No. 881554 (7th Cir. Feb. 16, 1989).

${ }_{179}$ See TASK FORCE REPORT, supra note 1, at 73-74.

180 Golden Eagle Distrib. Corp. v. Burroughs Corp., 801 F.2d 1531, 1540 (9th Cir. 1986).

181 See TASK FORCE REPORT, supra note 1, at 62.

182 See supra text accompanying notes 123-24.

183 Even in the Third Circuit, whose Court of Appeals has emphasized the availability of non-monetary sanctions, see Gaiardo v. Ethyl Corp., 835 F.2d 479, 482-83 (3d Cir. 1987); Lieb v. Topstone Indus., Inc., 788 F.2d 151, 157-58 (3d Cir. 1986), twenty-one of twenty-seven sanctions imposed in the survey period were monetary, eighteen of which were made payable to another party. See TASK FORCE REPORT, supra note 1, at 36-37. Moreover, fourteen of the eighteen expense-shifting sanctions were calculated on an attorney's fee model. See id. at 113-14.

${ }^{184}$ Complaints were the object of $50 \%(70 / 140)$ of Rule 11 motions and sua sponte impositions in the Task Force's survey period. See TASK FORCE REPORT at 110; see also supra note 69 and accompanying text.

${ }^{185}$ Cf. Evans v. Jeff D., 475 U.S. 717, 758 (1986) (Brennan, J., dissenting) (professional ethics may require a defendant's counsel to seek waiver of attorney's fees as a condition of settlement in a civil rights case).

186 See supra text accompanying notes 174-78; infra text accompanying notes 194-95. For Seventh Circuit cases reversing denials of Rule 11 sanctions by trial courts or requiring consideration of such sanctions, see Fred A. Smith Lumber Co. v. Edidin, 845 F.2d 750 (7th Cir. 1988); S.A. Auto Lube, Inc. v. Jiffy Lube Int'l, Inc., 842 F.2d 946 (7th Cir. 1988); Frantz v. United States Powerlifting Fed'n, 836 F.2d 1063 (7th Cir. 1987); Szabo Food Serv., Inc. v. Canteen Corp., 823 F.2d 1073 (7th Cir. 1987), cert. dismissed, 108 S. C. 1101 (1988); Shrock v. Alton Nurses Registry, 810 F.2d 658 
A study might find, in other words, that Rule 11 motions are made much more frequently in the Seventh Circuit than they are in the Third. It seems less clear to me, however, what comparative conclusion would emerge as to directly associated costs, including the costs of satellite litigation. Difference in frequency of invocation by parties (and of sua sponte imposition) is not the only variable. Indeed, one attraction of a product approach to, and a possible consequence of a compensatory perspective on, Rule 11 is procedural minimalism in the imposition of sanctions. ${ }^{187}$ But, I expect, the Supreme Court eventually will put an end to the notion that a person sanctioned under Rule 11 is not entitled to prior notice and opportunity to be heard because a hearing would be "pointless"188 or because a motion for reconsideration is an adequate substitute. ${ }^{189}$ Moreover, it is open to doubt whether a sanction-firstask-questions-later procedure is efficient even taking a narrow view of costs. Lawyers and their clients have a nasty habit of seeking reconsideration when they have not been heard, and even an opinion on reconsideration may not dissuade them from taking an appeal, perhaps because they have not been persuaded that the reconsideration process was more than a feint. ${ }^{180}$

In any event, whatever savings result from procedural minimalism in the imposition of sanctions in the Seventh Circuit may be eaten by the costs of litigating and deciding Rule 11 motions that are denied and by the costs of appeals. Viewing Rule 11 as a "fee-shifting statute"191 and assimilating it to no fewer than three torts ${ }^{192}$ have led to the imputation of rights to a party seeking Rule 11 sanctions and the imposition of a duty of explanation on district judges in the Seventh Circuit. ${ }^{193}$ Moreover, even a formally deferential standard of appellate review, in the hands of some judges applying it, can only encourage those ag-

(7th Cir. 1987); Dreis \& Krump Mfg. v. International Ass'n of Machinists, 802 F.2d 247 (7th Cir. 1986); Tarkowski v. County of Lake, 775 F.2d 173 (7th Cir. 1985) (Rule 11 and $\S 1988$ ).

187 See TASK FORCE REPORT, supra note 1, at 26-27, 73-74.

188 See Hill v. Norfolk \& W. Ry., 814 F.2d 1192, 1202 (7th Cir. 1987) (discussing FeD. R. APP. P. 38); see also United States v. Childers, 846 F.2d 74 (4th Cir. 1988) (text in WESTLAW and LEXIS) (Rule 11). But see TASK FORCE REPORT, supra note 1 , at $27-29$.

${ }_{188}$ See Rodgers v. Lincoln Towing Serv., Inc., 771 F.2d 194, 206 (7th Gir. 1985).

But see TASK FORCE REPORT, supra note 1, at 32-33.

190 See TASK ForCe REPORT, supra note 1 , at 33, 81.

101 Hays v. Sony Corp., 847 F.2d 412, 419 (7th Cir. 1988).

192 See id. at 418 ("Rule 11 defines a new form of legal malpractice"); Szabo Food Serv., Inc. v. Canteen Corp., 823 F.2d 1073, 1083 (7th Cir. 1987) (abuse of process and malicious prosecution), cert. dismissed, 108 S. Ct. 1101 (1988).

${ }^{193}$ See TASK FORCE REPORT, supra note 1, at 35-36; supra text accompanying note 176. 
grieved by a deprivation of their right to compensation to seek review. ${ }^{194}$ Finally, it cannot be long before the Seventh Circuit adds to the incentives by overtly approving what it, in effect, has endorsed already: the prospect of expenses on appeal if litigants are successful in challenging the denial of Rule 11 sanctions. ${ }^{185}$

But all of this speaks to costs. What of benefits? I expect that a survey of lawyers practicing in the Seventh Circuit would find effects on practice even more widespread than the effects the Task Force found in the Third Circuit. ${ }^{186} \mathrm{I}$ hope that those conducting the study would be more sophisticated in their instrument design than we were. ${ }^{197}$ In addition, it is essential not to equate evidence of effects on practice, such as counselling clients not to file complaints or other papers, effects on settlement, or effects of warnings, with benefits. ${ }^{198}$ Indeed, even an effect as apparently benign as enhanced pre-filing legal inquiry may be misleading. At some point, such inquiry may not be justified, particularly in light of the rate at which cases are settled. It seems to me that this point is likely to be reached as often in the Seventh Circuit as anywhere else in the country, because some judges there seem "intent on, or indifferent to the implications of, using the Rule to mold the bar in their own image."189

The Third Circuit Task Force was reassured that most of the effects on practice noted by respondents to its attorney questionnaire that

194 See Brown v. Federation of State Med. Bds., 830 F.2d 1429, 1434 (7th Cir. 1987) (asserting that previous decisions had applied a de novo standard of review without discussion).

195 See Hays, 847 F.2d at 419 ; S.A. Auto Lube, Inc. v. Jiffy Lube Int'l, Inc., 842 F.2d 946,950-51 (7th Cir. 1988). But see TASK FORCE REPORT, supra note 1, at 49$52,98-100$.

${ }^{196}$ See supra text accompanying note 165.

197 See TASK FORCE REPORT, supra note 1, at 148.

198 See id. at 76-77, 84-86; supra text accompanying note 165.

199 TASK ForCE REPORT, supra note 1, at 21; see, e.g., Hays, 847 F.2d at 419 ("A lawyer who lacks relevant expertise must either associate with him a lawyer who has it, or must bone up on the relevant law at every step along the way in recognition that his lack of experience makes him prone to error."); Thornton v. Wahl, 787 F.2d 1151,1154 (7th Cir. 1986) ("Rule 11 requires counsel to study the law before representing its contents to a federal court").

The approach revealed in Parts IV and V of the majority opinion effectively transforms Rule 11 from a protector against frivolous litigation, a boon to the parties and the courts, into a fomenter of derivative litigation, a mine for unwary parties and overzealous courts. In addition, under this approach the judicial process becomes a task not unlike the grading of law school examinations. Presumably the submissions of the parties are to be marked on a scale of " $A$ " through " $F$ ". Anything falling on the far side of " $C$ " merits not only loss of one's case but loss of one's shirt as well.

Szabo Food Serv., Inc. v. Canteen Corp., 823 F.2d 1073, 1085 (7th Cir. 1987) (Cudahy, J., concurring and dissenting), cert. dismissed, 108 S. Ct. 1101 (1988). 
could be taken as evidence of benefits should be so taken. For example, although $26 \%$ of the respondents indicated that, in their view, the amended Rule had chilled legal development, $74 \%$ perceived no such effect. Moreover, only five percent indicated that it had affected their practice in seeking extension or change in the law. ${ }^{200}$ Would the same be true in the Seventh Circuit, where plaintiffs and their lawyers at least must worry about, if not expect, an aggressive approach to Rule 11 sanctions and where they risk routine and potentially devastating expense-shifting sanctions if they guess wrong about judicial reactions to the papers they file?201 The question refers to "plaintiffs and their lawyers" because I would expect the differential impact of the Rule on that group to be even greater in the Seventh Circuit than it is in the Third, ${ }^{202}$ assuming district court judges practice what some appellate judges preach. Obviously, the study I have in mind should pay close attention to civil rights plaintiffs and, in particular, to $\S 1983$ plaintiffs, for whom a product approach and a compensatory perspective pose special difficulties. ${ }^{203} \mathrm{I}$ hope that it also would attempt to answer questions about differential impact on the poor. ${ }^{204}$

Finally, the Seventh Circuit study I recommend may be able to shed additional light on other collateral consequences (costs) of Rule 11. The Task Force's interviews for the Third Circuit study did not support the notion that expense-shifting (or other monetary) sanctions are viewed as "only money," $20 s$ a notion that evidently prompted a 1981 proposal to distinguish between expense-shifting and "sanctions." 206 But that may be a function of legal culture, which in turn may play a major role in determining reputations and hence in affecting the allocation of legal business. ${ }^{207}$ On the other hand, our inquiries about the effect of Rule 11 on bar discipline suggest that it would be a fruitful area of further study in the Seventh Circuit. ${ }^{208}$ In addition, it may be a coincidence that the Task Force's only evidence of direct inquiry about Rule 11 on an application for professional liability insur-

200 See TASK FORCE REPORT, supra note 1, at 84-85. As noted there, some participants at the Third Circuit Judicial Conference regarded even the five percent figure as cause for concern.

201 See supra text accompanying notes $39-43,175-78,182-86$.

202 See supra text accompanying note 65.

203 See TASK Force REPORT, supra note 1, at 71-72; see also supra text accompanying notes $71-76$.

${ }^{204}$ See supra text accompanying notes 141-42.

203 See TASK FORCE REPORT, supra note 1, at 26-27, 38.

208 See TASK FORCE REPORT, supra note 1, at 37-38; Analysis of Comments, supra note 141 , at 12 .

207 See TASK FORCE REPORT, supra note 1, at 37-38.

208 See id. at 89-90. 
ance came from a lawyer based in the Seventh Circuit. ${ }^{208}$ But, then again, it may not be a coincidence.

As the Task Force observed, "[p]redictions are cheap."210 Perhaps my speculations about the possible results of empirical study in the Seventh Circuit are "cheap" in more ways than one, insofar as they flow from normative analysis that is based on only some of the signals sent by the Court of Appeals. But which signals are lawyers, who cannot predict the makeup of an appellate panel, likely to regard as important in the mix? In any event, my speculations will not have a direct effect on lawyers' reputations and livelihoods, and presumably judges who are quick to criticize lawyers can take a little criticism themselves. However unfair they are, therefore, my speculations pale in comparison with the unfairness of pursuing sanction theories in the absence of facts, particularly theories that are in tension, if not direct conflict, with basic premises of our legal system and with the articulated premises of Rule 11.

\section{ConClusion}

The rhetoric of procedural reform has hardly changed over the course of a century, but much of it is empty rhetoric. ${ }^{211}$ Many Federal Rules of Civil Procedure are only superficially uniform and hence only superficially trans-substantive. ${ }^{212}$ Practice under them is not uniform, and neither is it simple or predictable, because under them lies a vast underworld of local rules, standing orders, and, ultimately, judicial discretion. ${ }^{213}$ Adjudication on the merits has long since become a scarce

209 See id. at 90-91. The information was provided by a member of the Task Force who practices in the Seventh Circuit.

$210 \mathrm{Id}$. at 96.

211 A particularly depressing example of such rhetoric was invoked by Senator Heflin in explaining the Senate Judiciary Committee's determination to preserve the system by which valid Federal Rules supersede previously enacted statutes with which they are inconsistent:

[The supersession clause] provides a sense of stability and uniformity to the Federal Rules of Procedure. As one witness testified at the hearing: "It has enabled the Rules of Procedure to be applied uniformly and has given confidence to lawyers and to litigants that the mechanics of filing a complaint, responding to an answer [sic], conducting discovery, and trying a case, will not vary between one type of Federal lawsuit and another."

134 Cong. Rec. S16,296 (daily ed. Oct. 14, 1988) (citation omitted) (statement of Sen. Heflin). The example is "particularly depressing," because the rhetoric was both empty, see supra text accompanying notes 18-85, and effective. See Pub. L. No. 100702, § 401(a), 102 Stat. 4642, 4648-50 (1988), quoted supra note 2. For further discussion of reform rhetoric, see Burbank, supra note 117," at 427.

${ }^{212}$ See supra text accompanying notes 18-23.

213 See supra text accompanying notes $18-23$ \& 88-90. 
commodity, and the quest for the "speedy and inexpensive determination of every action"214 threatens, in some quarters, to become synonymous with the "just" determination of those actions.

Viewed in the context of the amendments of the Eighties, Rule 11 is part of a transformation, characterized by enhanced awareness of the folly of advertising apples as oranges and vice-versa. One question for the future is whether, and to what extent, we shall continue to leave it to individual federal judges (or judicial surrogates) ${ }^{215}$ to decide which is which. Another is whether, whoever decides, the decision will be informed by experience beyond that of the people making it. In responding to both questions, we should recall other transformations, both that of the original Federal Rules of Civil Procedure and that of amended Rule 11 itself. If those with the power of discretion are unwilling to surrender any of it, let us at least hope that they will also seek the power of facts. 


\section{APPENDIX}

\section{LAW SCHOOL OF HARVARD UNIVERSITY}

Cambridge 38, Mass.

March 2, 1967

Dean Acheson, Esq.

Covington \& Burling

701 Union Trust Building

Washington 5, D.C.

Dear Mr. Acheson:

You may recall that a suggestion out of the usual course was made at our Committee meeting in Spring 1966. At that time we had completed action on our third set of Rule amendments, and were beginning to see the end of the Discovery problem. We all realized that the examination of the Rules which had begun in 1960 was shortly going to grind to a halt - a temporary halt, to be sure, but still a halt - and we all had in our minds the question of quo vadis. In this setting, John Frank (seconded by Gharles Wright, and, I think, Bert Jenner) raised the question whether our Committee should not turn its attention to large procedural themes such as "delay in the courts" which in the end are far more important than technical questions of Rule amendments.

It was left to me to think about the suggestion and make some response to it. I assumed that I was allowed a generous moratorium, but recently I have done what thinking I could, have spoken with my colleagues at Harvard including Albert Sacks, and, on trips to New York, Chicago, and New Haven, have had words, respectively, with Maurice Rosenberg, Geoffrey Hazard (who directs research for the American Bar Foundation), and Fleming James (whose most recent procedural exploit was to bring out a very fine text, American Civil Procedure). ${ }^{*}$ Without rehearsing what was discussed at these purposely desultory sessions, I would like to set out some impressions that I derived from the talks.

1. Glearly it would be a mistake to try to run a project like the one envisaged by John Frank according to our usual routine, with a Reporter working up a paper with proposals, and the Committee criticizing and reshaping the proposals and finally voting a solution. The subject matter would simply not lend itself to any such routine. Suppose we tried to decide what to do about accident cases in relation to delay. How would a Reporter attack this? To whom would our solution be

* Of course none of these gentlemen is implicated in responsibility for the content of this letter. 
addressed, and with what claims of authority or validity?

The inappositeness of our regular procedure is obvious, but I want to make the further point that our Committee ought to be careful about lending its official sponsorship to a project in such a field as "delay" even if a reasonable pattern of work, perhaps by other hands, could be devised. Such a project would not be quite germane to our delegated authority. And as soon as one gets into issues like delay, a "political" element may enter. To involve the Committee in public debates of that sort creates a possibility of putting at risk the reputation for impartiality and scientific skill which the Federal rulemakers have been at pains to build up since the 1930 s. These are only cautionary words. I am not suggesting that the Committee must take a completely hands-off attitude toward all projects other than those bearing immediately on the Rules.

2. Still considering questions of format, I should add that I do not think it would make sense to dissipate the Frank suggestion by just holding another conclave on an Arden House model. In fact there has been just such a conclave on the subject of the courts, and a good one, in the past couple of years, to which, as I recall, Professors Rosenberg and Hazard made excellent contributions. At best an Arden House meeting produces a summary of what is known or believed to date. It is not a substitute for original research into dark places.

3. Thus the Frank suggestion seems to me finally to raise the question whether we can imagine a research project in civil procedure, under whatever auspices, that at this particular stage of history might claim to have large importance or promise.

It was instinct in the original suggestion that we should not play around with mere gadgetry, or with merely visionary proposals, or with the run of tired ideas regularly dusted off and advanced as cure-alls. In one or another of these categories I would put ideas of changing the balance between the written and oral elements of the procedure - e.g. increased emphasis on summary judgement or like devices; installing Masters to take the burden off judges during pretrial stages; abolishing the constitutional requirement of jury trial; changing the law governing allocation of expenses of litigation; and a hundred other notions that pop up repeatedly in the literature and trade-talk of lawyers. (I have dared to mention here some ideas listed by John Frank in a letter elaborating upon his own suggestion.) It is not that these ideas are all transparently so poor as not to be entitled to study on their merits. Some of them may well deserve study by someone. None of the usual array, however, qualifies as the center of a research that might make an important contribution to the progressive evolution of civil procedure, 
although some of them might be ultimately caught up as collateral parts of such a research.

4. Upon consideration of various possibilities, I am personally attracted by a basic research, both theoretic and empiric, with three interlocking phases or aspects as follows. I set these down flatly, with no attempt at elaboration.

(a) The first phase of the research would try to answer the question: Which quarrels under present-day conditions belong in the courts (constituted more or less as the courts now are), and which do not? This inquiry is in part philosophic, in part practical. Do "family" or probate matters belong in the courts? One would finally ask the same questions about accident cases. As the research found that particular blocks of controversies are not suited to courts, it would have to go on to answer the question where they do belong, and on what terms. The inquiry could not stop short of substance. Thus changes in substantive rules or other arrangements could affect the choice of the agency to settle particular kinds of disputes, or even eliminate the disputes altogether.

(b) The second phase would be an attempt to classify the various types of court-litigated matters by their intrinsic qualities and functions with a view to deciding whether the unitary court procedures now in vogue could be deliberately altered to accommodate better to the several types. The general advantages of a unitary or common procedure are evident, but that may be overborne by other considerations in certain classes of cases. As in (a) above, a study of this kind, while centering on procedure, could not remain totally procedural. The various classes of cases could be understood only if their substantive settings were appreciated, and this means an analysis of the relevant social and economic facts as well as the controlling material rules of law.

It would be well to attempt to sort out litigated cases on a variety of bases besides the functional. For example, we have never pursued the full implications of a decision that small cases should not be able to claim the same refinements of procedure as big cases.

(c) The third phase of the study would be an attempt to apply "systems analysis" (connected, I believe, with what was called "operations research" during the War) to the workings of the courts. I am in the unhappy situation of not knowing exactly what is meant by systems analysis, but I think we are all entitled to satisfy our natural curiosity about what computers, flow charts, and the rest of the paraphernalia could do in making the business of justice more efficient. As adjunct to systems analysis, I would insist upon experimentation with live cases to the extent that this would not involve illegal discriminations among 
litigants.

You will find in the recent report of the President's Crime Commission a brief reference to an investigation into the workings of a District of Columbia court that qualifies as a "systems analysis" in my lexicon and is quite impressive. (See The Challenge of Crime in a Free Society, pp.257-59). Full-scale explorations on similar lines would, I am sure, be very instructive.

5. If the research just outlined makes any appeal as being basic and important, we still have the question just how it can be promoted and carried out. This I will leave to the next chapter, if any, except to note a Presidential recommendation bearing on the question that came out at about the time I had finished my private deliberations. As part of his message on Crime, the President proposed the creation of a "judicial center" within the Administrative Office of United States Courts which is (i) to conduct research and tests in judicial administration, and (ii) to carry out programs of education and training for personnel in the judicial branch, including judges. I do not know the exact origin of the recommendation; it has been intimated that the Chief Justice inspired it. Senator McClellan on February 8, 1967 introduced legislation (S. 915) to carry out the recommendation, and I annex the major provisions of the bill. If the bill should pass, it is conceivable that the research I have suggested could be carried out by or under the auspices of the judicial center. Under the terms of the bill, I believe the judicial center could perform effectively notwithstanding the fact that the deepest and most resistant problems lie on the State rather than on the Federal level. It is a matter for consideration just how our Committee could give continuing help or support to the judicial center in the research.

I submit this letter as a basis for a discussion by the Committee if you think a discussion would be profitable. I am taking the liberty of sending copies to Messrs. Frank, Wright, and Jenner; if further distribution is desired, I would be glad to take care of it.
All best regards, Yours sincerely, Benjamin Kaplan

BK: cwm

cc: Mr. Frank, Mr. Jenner, Professor Wright

[Annex containing excerpts from S. 915, 90th Congress, 1st Session not included.] 


\section{.}

. . 